\title{
Beheading the Hydra? Does Killing Terrorist or Insurgent Leaders Work?
}

\section{Keith Patrick Dear}

To cite this article: Keith Patrick Dear (2013) Beheading the Hydra? Does Killing Terrorist or Insurgent Leaders Work?, Defence Studies, 13:3, 293-337, DOI: 10.1080/14702436.2013.845383

To link to this article: http://dx.doi.org/10.1080/14702436.2013.845383

$$
\text { ( ) } 2013 \text { The Author(s). Published by Taylor \& }
$$

\section{Published online: 05 Dec 2013.}

Submit your article to this journal

$$
\text { LII Article views: } 5876
$$

\section{Q View related articles $\asymp$}

Citing articles: 2 View citing articles $₫$ 


\title{
Beheading the Hydra? Does Killing Terrorist or Insurgent Leaders Work?
}

\author{
KEITH PATRICK DEAR
}

If Alexander's thoughts had not been set on high emprise ... would he not have grown tired and weary of ... unnumbered revolts, desertions, and riots of subject peoples ... as if he were cutting off the heads of a hydra which ever grew again in renewed wars among these faithless and conspiring peoples? ${ }^{1}$

Plutarch - On Alexander's 4th century BC campaign in Bactria, modern-day Afghanistan.

As Alexander was troubled by the hydra-like nature of his Afghan opponents so today is NATO. The Taliban's leadership has been pursued continuously and ever more intensely since the start of the conflict in 2001, and is now being killed, according to senior American and British commanders, 'on an industrial scale'. ${ }^{2}$ Twelve thousand insurgents were reportedly killed or captured by Special Forces in 'night raids' targeting named individuals in the 12 months to May 2011 while there were 350 night raids in the first four months of 2012 alone. ${ }^{3}$ Coalition air forces have also increased targeted killing, though statistics are publically unavailable. ${ }^{4}$ CIA 'drone strikes' in Pakistan, aimed at the killing of members of Al-Qaeda and related groups, are better documented and have increased significantly since 2008. The US began such strikes in 2004 and conducted only 10 until 2008; there were over 100 in 2010, 72 in 2011 and 43 to date in $2012 .^{5}$ Under both programmes, individuals are listed in advance and killed or captured when possible. British Special Forces have been in the forefront of targeted killing campaigns in Afghanistan and Iraq, and British 'drones' are now deployed in Afghanistan to the same end. ${ }^{6}$ Insurgent and terrorist cells are being relentlessly 'decapitated' by targeted strikes, but the hydra-like insurgency is now active over a wider area and the insurgents more numerous than ever. ${ }^{7}$ The question then, is does targeted killing work?

Keith Patrick Dear, ${ }^{\mathrm{a}} \mathrm{RAF}$. 
Some definitional clarity is required. Attempts to define terrorism have proved elusive; terrorism remains 'an essentially contested concept'. Herein it is a tactic, understood in the modern Maoist sense, after John MacKinlay, as a means among a number by which an insurgent group aims to achieve political ends. ${ }^{9}$ Terrorism, then, is 'an arm of the revolution', a tactic used by violent political activists. ${ }^{10}$ Violent political activists without popular support are no more than armed thugs. Their use of violence will only increase their unpopularity, increasing their vulnerability to exposure, denouncement, arrest, disruption or punishment. ${ }^{11}$ This paper is interested in insurgent groups, many of which use terrorism as their primary tactic, but which are sustained by sympathetic supporters and enjoy a degree of popular legitimacy. Therefore I prefer the term 'insurgent' to 'terrorist'.

The debate surrounding targeted killing's efficacy is often polarised between two extremes: that targeted killing is essential to defeat insurgents and terrorists or that it does not contribute to their defeat and may make their defeat less likely. ${ }^{12}$ Regardless of the conclusion, there are three main approaches to judging targeted strikes' efficacy. First, a quantitative, social science approach which relates statistics, such as the number of attacks an insurgent group carries out before a targeted killing, to the number carried out after, and uses a reduction or increase to argue that tactic was effective or ineffective. ${ }^{13}$ Second, there is the qualitative approach, wherein specific insurgencies are analysed and the effectiveness of targeted killing judged against the historical record. ${ }^{14}$ Third, there is the ideological approach, which holds either that targeted killing is morally indefensible, or that killing 'bad people' is a good thing. ${ }^{15}$ My aim is to contribute to the debate on targeted killing's efficacy and therefore the focus is not on the moral dimension. Discussion of targeted killing often focuses on civilian casualties, since the tactic is not always as precise as advocates claim. Some argue that the civilian casualties that result from targeted killing render it ineffective, or exacerbate its counterproductive effects. ${ }^{16}$ However, focusing on civilian casualties would distract from and obscure the discussion herein, suggesting that if targeting killing could be conducted with absolute precision, it would be effective. Although examination of the effect of civilian casualties caused by targeted killing would strengthen many of the points made in this paper, this aspect is not explored as it is taken as axiomatic that civilian casualties are counterproductive. The more important point that emerges from this examination is that even if targeted strikes caused no civilian casualties, they may still be ineffective. 
I have followed a qualitative approach, using case studies and the historical record to judge targeted killing's effectiveness, drawing on the statistics where necessary. In order to bridge the gap between the academic and military debates, a series of semi-structured interviews with experts from both domains and multiple countries were conducted. These provided a glimpse behind the curtain of secrecy that shrouds much of the justification for targeted killing, as well as giving insight into the current thoughts of practitioners and commentators.

I find that targeted killing, in certain limited and specific circumstances, can have an advantageous tactical effect, as part of a wider strategy. I reject the notion that targeted killing is an effective strategy on its own. This last point is more than just a straw man; there is a growing argument in favour of targeted killing as a counterterrorist strategy both within and beyond Afghanistan. ${ }^{17}$ The seductive lure of such arguments to policy-makers requires robust rebuttal if the debate and policy are not to move in a direction that would exacerbate the problem they seek to resolve. It is useful then to describe how the debate has moved to a point where targeted killing is considered a viable strategy for fighting terrorism and insurgency.

For 25 years the US held that assassination in conventional and irregular warfare was immoral, a belief enshrined in 1976 in Executive Order 11905 and upheld until 2001. ${ }^{18}$ Ahead of the 1991 Gulf War, US Air Force Chief of Staff General Michael J. Dugan suggested that Saddam Hussein and his senior commanders might be targeted in 'decapitation' strikes against the regime. He was abruptly sacked by Defense Secretary Dick Cheney. Cheney explained that it was 'inappropriate for US officials to talk about targeting specific foreign individuals' which was 'potentially a violation of the standing Presidential executive order' prohibiting assassination. ${ }^{19}$ Discussing targeted killing as a part of Israel's counterterrorist strategy in July 2001, the US Ambassador to Israel warned 'The United States government is very clearly on record as against targeted assassinations. ... They are extrajudicial killings' ${ }^{20}$ Seven days before 9/11, George Tenet, then CIA director, argued in reference to the use of armed drones that it would be 'a terrible mistake' for 'the Director of Central Intelligence to fire a weapon like this'. ${ }^{21}$ Leon Panetta shut down a CIA draft plan developed to respond to $9 / 11$ as Israel had to the murder of its athletes in Munich: by sending assassination teams to hunt and kill suspected Al-Qaeda members. Still the plan caused significant political controversy when knowledge of it became public. ${ }^{22}$ Despite the controversy, the US is now the world's foremost practitioner of targeted 
killing, a practice institutionalised in doctrine, and likely to be central to US strategy in and beyond the current Afghan campaign. ${ }^{23}$

Britain's tradition contains no explicit ban on assassination, but the British have avoided pursuing leadership targets because experience taught that these were the men with whom an agreement would have to be made when the time to talk arrived. A pertinent example is the late 19th century British policy of 'butcher and bolt' towards the indirectly ruled tribal frontier of India, today's Federal Administered Tribal Areas (FATA). Under this policy a military expedition responded to unrest by taking over villages and destroying the homes of the revolt's leaders. The leaders of the revolt were not killed in order to avert a blood feud, which would have escalated the violence. ${ }^{24}$ But even the destruction of houses served only to deepen the Pashtuns' hostility towards the British, with each punitive expedition bringing more raiders down from the hills to murder and pillage. ${ }^{25}$ In the end, the British turned to a policy of co-option, wherein the fielded forces of the uprising were defeated, following which the leadership was co-opted or bought off to prevent any repetition. ${ }^{26}$ This model predominated throughout the years of Britain's retreat from Empire. ${ }^{27}$ Its abandonment in recent 21 st century conflicts has surprised some retired senior officers, including General Sir the Michael Rose, who recalled his time during the Dhofar War, noting that many of his former adversaries are now active in the Sultan of Oman's government.

Targeted killing is set to dominate the US approach to defeating terrorism and insurgency over the next five years. The military and intelligence agencies will advocate for it, politicians will be a receptive audience, and the academic and media milieu favours it. General David Petraeus and Leon Panetta, former head of the CIA and US Secretary of Defense respectively, pioneered the use of targeted killing as a counterterrorist/insurgent tactic, their appointment and the widespread employment of the approach since Barack Obama's election suggest he favours it. ${ }^{28} \mathrm{~A}$ shrinking British military is increasingly configured for it, having doubled the number of Reaper 'drones' in its inventory, and increased funding for Special Forces. ${ }^{29}$ The US Congress has expanded the use of targeted killing to Yemen, and Somalia. ${ }^{30}$ In 2009 President Barack Obama accepted Vice-President Joe Biden's advice to pursue a strategy including targeted killing in Afghanistan and in Pakistan's border areas (labelled 'counterterrorism lite' by the media), but also accepted the military's request for a counterinsurgency approach. ${ }^{31}$ Obama's pre-election opposition to the 'surge' in US troop numbers in Iraq, which was believed at the time to be responsible for the remarkable improvement in 
US fortunes there, made it difficult for him to oppose counterinsurgency advocates. In addition to pressure from the military, the media and academic environment at the time constrained Obama's decision. As a senior Presidential adviser and former aide to Petraeus in Iraq wrote at the time "counterinsurgency is king...[it]...is on the verge of becoming an unquestioned orthodoxy'. ${ }^{32}$ Academics, the military and the media, are no longer in thrall to the ideas of counterinsurgency (COIN) theorists. ${ }^{33}$ 'Drone strikes' and night raids have been judged successful while COIN has not achieved the stunning results in Afghanistan that it appeared to have in Iraq. $^{34}$ General Petraeus shifted to a more coercive than persuasive policy in Afghanistan, an approach set to continue as COIN forces leave and Special Forces and aircraft remain beyond 2014. ${ }^{35}$ Biden's 'counterterrorism lite' is now seen as a viable alternative. ${ }^{36}$

This study measures targeted killing against its aims. Air Marshal Nickols, the UK's former Chief of Defence Intelligence, suggests that counterinsurgent forces kill or arrest key members of insurgent groups, known as High Value Targets or Medium Value Targets (HVTs/MVTs) in order to affect a group's capability and psychology; all the security officials interviewed for this study argued similarly. ${ }^{37}$ This provides a useful analytical framework. Therefore, in section 1, I examine the effect of targeted killing on a group's capability, finding that it does make a group less capable in the short term. In section 2, I examine targeted killing's effect on group psychology, concluding that it is unlikely to achieve the psychological effects the counterinsurgent intends. In section 3, I examine targeted killing in cultural context, finding that in pre-modern societies, such as those in Yemen, Somalia and Afghanistan, local culture increases the negative psychological effects of targeted killing. In section 4, I describe the nature of the evolution that targeted killing forces groups to undergo, finding consistent results across the ten conflicts studied: in the long-term it unites insurgents, and brings forward a younger, more radical leadership which makes the group more indiscriminately violent; I then explain why the dangerous effects of targeted killing have been so long ignored. In section 5, I examine the evidence against my argument. In concluding, I argue that targeted killing can be tactically effective but is strategically counterproductive. Finally, I present policy advice based on my findings.

\section{Targeted Killing and Insurgent Capability}

Capability is demonstrated by how frequently an insurgent group can launch attacks, how many attacks they can launch and how lethal and 
damaging their attacks are. This is dependent on the insurgent groups' ability to coordinate and their expertise. Targeted killing aims to remove the coordinators and experts on whom an insurgent group depends.

Turning first to coordinators: targeted killing aims to disrupt insurgent command and control by targeting their leadership to remove key leaders disrupting their attack plans and hindering future plans as those that remain fear attack and hide. $3^{38}$ When targeted killing is undertaken for a discrete purpose, targeting a specific individual known to be coordinating a specific attack in a specific location its immediate effect is to disrupt planning and it may prevent an attack. In the short term it disrupts planning by forcing remaining leaders to reduce meetings with others, avoid traceable communication devices, move often, and to trust with caution to avoid detection and reduce their vulnerability. ${ }^{39}$ With repeated use targeted killing's effect on insurgent command and control, and more broadly their capability, is subject to a law of diminishing returns and may ultimately be counterproductive.

The immediate disruption caused by killing an individual known to be planning an attack cannot be disputed. There is evidence for the disruption to command and control (C2) and capability caused in the short-term. Western police report that fewer terrorist plots have been discovered since the targeted killing campaign against Al-Qaeda began in Pakistan. ${ }^{40}$ Al- Qaeda's changing tactics further evidence its reduced C2. Al-Qaeda had previously rejected the idea of 'lone-wolf terrorism', based on individual initiative, rather than central coordination. ${ }^{41}$ Their recent adoption of the approach is testament to their diminished ability to coordinate attacks centrally. ${ }^{42} \mathrm{Al}$ Qaeda's reduced $\mathrm{C} 2$ cannot be attributed entirely to targeted killing. Numerous other factors, such as improved counterterrorist security and greater international counterterrorist cooperation are crucial.

Over the medium to long-term the effects are limited. Al-Qaeda's command and control may relocate, as it did in Pakistan in 2001 on eviction from Afghanistan, ${ }^{43}$ and in Yemen following disruption in Saudi Arabia (by arrest, not targeted killing). ${ }^{44}$ Recent plots and attacks against the West conceived in the North-West Frontier Province (NWFP) indicate the limitations of disruptive efforts. ${ }^{45}$

In Afghanistan less effective insurgent $\mathrm{C} 2$ would be evidenced by a reduction in the Taliban's ability to conduct tactically complex attacks, and a reduction in their ability to synchronise attacks across a wide geographic area. The Taliban, by contrast, today conduct attacks as complex, if not more so, than ever before, and continue to show the capability to coordinate and conduct attacks across a wide geographic area 
simultaneously. ${ }^{46}$ Some evidence suggests that killing leaders may not reduce insurgent capability either to coordinate attacks or to sustain levels of violence. When Abu Musab al-Zarqawi was killed in Iraq his death had little effect if we measure this by the ability of his group to conduct attacks: violence increased in the months following his killing. ${ }^{47}$ Similarly, a week after Mullah Dadullah Lang was killed in Afghanistan the Taliban in his area of operations overran the town of Ghorak. ${ }^{48}$ Despite the limitations and other contributory causes, the logic and the evidence suggest targeted killing can disrupt insurgent C2 in the immediate and short-term.

The repeated use of targeted killing on insurgent capability is, however, subject to a law of diminishing returns and may be counterproductive. Those leaders unable to maintain a sufficiently clandestine profile will be killed leaving only the competent alive. ${ }^{49}$ The youthful leadership that emerges, and the older leadership that survives, will know to move regularly, limit their communications, switch off their satellite and mobile phones, and to trust fewer people with information. ${ }^{50}$ It is often claimed that this hinders their ability to coordinate large-scale attacks. There is no evidence for this in Afghanistan, fast becoming the test case for targeted killing, where insurgent attacks are today more complex and large scale than ever before. It does however eliminate or reduce the ability of the counterinsurgent to monitor and thwart insurgent plans.

Less centralised C2 and increased operational security requirements mean that a local insurgent commander would receive less micro-management over communications networks, and instead would be given general guidance that he can interpret according to local conditions. This is 'mission command', which is advocated by the British military as the most effective form of leadership. The enforced adoption of Mission Command as the structural foundation of an insurgency will further encourage innovation. ${ }^{51}$

Taliban resilience to leadership targeting may be a product of the decentralisation of $\mathrm{C} 2$ in response to leadership targeting, but Afghan society, and particularly Pashtun society, is traditionally fractured and fragmented, and this may be the more important factor. The fragmented nature of the Taliban has been evident to mediators in the conflict. Seeking to bring insurgents into the peace process they have been forced to work on a piecemeal, district-by-district basis, demonstrating that Taliban C2 is not dependent on mid-level commanders. ${ }^{52}$ The vast majority of insurgents are known to fight within two to three kilometres 
of their homes, further suggesting that the insurgency in Afghanistan is fragmented by nature. ${ }^{53}$

Whatever the cause of the Taliban's 'fragmented', decentralised C2 that very few have reconciled suggests that fragmentation is not the same as disunity. ${ }^{54}$ The Taliban can and have maintained unity through 'spectacular' attacks to ensure they continue to be seen as the mouthpiece for the insurgency. Such propaganda of the deed enables them to frame the narrative in such a way as to maintain unity of purpose even as they preside over a highly decentralised network. ${ }^{55}$

Attempts to fragment the insurgency by destroying C2 may be counterproductive. Isolated cells are more innovative than hierarchical bureaucracies. Just as small, well-motivated, egalitarian companies are often more innovative than larger established hierarchical corporations, so social theory suggests unified groups with limited external links will be more innovative than those that are part of a clear hierarchical structure. ${ }^{56}$ An insurgent group made more cohesive through the psychological effects of targeted killing, and more cellular by the deliberate destruction of 'links', will probably be more innovative.

\section{Offensive Capability}

Targeted killing aims ultimately to reduce the number and lethality of insurgent attacks. This can initially be achieved in cases where an organisation has limited support and vulnerable hierarchical command. Over time the effect of each killing will reduce and in time it may be counter-productive as groups become more resilient, evasive and effective through a process of evolution and adaptation.

Two examples show how targeted killing can reduce insurgent technical capabilities, but they also demonstrate its limitations. In 1996 Israel killed Yahya Ayyash, nicknamed 'the Engineer' for his expertise in creating improvised explosive devices for suicide bombers. Colonel Roni Amir, head of doctrine for the Israeli Air Force, judges that the killing substantially reduced Hamas' capabilities for some time. In July 2008, British forces in Afghanistan killed Mullah Sadiq, a Taliban commander from Sangin, Helmand. ${ }^{57}$ Sadiq was believed to be behind a shift in Taliban tactics towards a greater reliance on IEDs. Brigadier Mark Carleton-Smith, Commander Task Force Helmand at the time, states that in the aftermath of Sadiq's death, there was a notable decline in the sophistication, and consequently the lethality, of the Taliban's IEDs around Sangin. ${ }^{58}$ 
Yahya Ayyash's killing may have temporarily reduced Hamas' capabilities, but there was an immediate backlash, four suicide bombings killed 60 Israelis in the days that followed, and there has been no lasting effect. Suicide bombings against Israelis increased in frequency and sophistication despite his killing. ${ }^{59}$ In the month after Mullah Sadiq was killed, British casualties to IEDs in Helmand fell dramatically, but they had returned to similar levels by May the next year and surpassed them two months later. ${ }^{60}$ The reduction in lethality of attacks may have been a consequence of the loss of Mullah Sadiq, and with him the loss of some of the Taliban's technical capability, but the effects were shortlived. The effect of killing Sadiq should have been heightened by NATO's killing of close to the entire Taliban leadership in Kandahar and Helmand province in the five months that followed, and the ever-increasing tempo of targeted killings in the area. ${ }^{61}$ Instead, the continuing casualties in the south of Afghanistan from IEDs suggest the killing of facilitators had no lasting effect on the Taliban's ability to build bombs. ${ }^{62}$ In the case of both Ayyash and Sadiq, targeted killing may have caused a temporary drop in insurgent technical capability, but it did nothing to reverse the tactical and technical trend. Killing 'experts' has limited effects in part because the level of expertise they require to be effective is so low that many can quickly learn the required skills. As Professor Ehud Keinan of the Israeli Institute of Technology has described, the manufacture of suicide vests is an 'embarrassingly easy' process. ${ }^{63}$

A US study of the Afghan conflict shows also that targeted killing of bomb-makers does not significantly reduce insurgent use of Improvised Explosive Devices (IEDs) or decrease the lethality of each device. ${ }^{64}$ The limited data released by the MOD on British casualty figures shows violence tracking seasonal trends relating more to the harvest, weather and ISAF (International Security Assistance Force) offensive operations than the killing of insurgent bomb-makers or leaders. ${ }^{65}$

The fracturing of finance networks achieved by killing or capturing financiers, and the cutting of finances by freezing financial assets is designed to reduce their capability by denying them funds. Its immediate effect is to force insurgents to raise finances locally and/or clandestinely. The Taliban have done this successfully, raising Usher, a tax on locals of 10 per cent, using Zakat, alms paid at the Mosque as a religious duty, as well as involvement in, and taxation of, the narcotics trade and funding through informal, difficult to track hawala networks. ${ }^{66}$ As a consequence the Taliban's local structures are now more autonomous, financially independent and thus resilient than prior to the targeting of the financial 
'links and nodes' in their network, a logical adaptation and perhaps standard insurgent response to such targeting.

The killing of arms smugglers is also undertaken to reduce insurgent capability. Lieutenant General Nick Parker claims that the rising cost of fertiliser in Southern Afghanistan, widely used to make explosives, shows a shortage of supplies. ${ }^{67}$ Given that this occurred when the Taliban network was being hit harder than ever by the targeted killing campaign, a case could be made that the price increase was a product of the reduced supply caused by a loss of facilitators. ${ }^{68}$ It should be noted that the price increase might equally have been caused by rising demand, not a shortage of supply, but the more important counterpoint is that fertiliser was still available, as were alternate sources of explosives. There is no shortage of conventional munitions in most unstable areas and it is easy to make effective IEDs with such materials. ${ }^{69}$ Therefore targeted killing will often have little lasting effect on insurgent capability to build bombs.

It has been suggested that the 13 April 2011 killing of Abu Hafs al-Nadji, a senior al Qaeda representative in Afghanistan, may have reduced the flow of foreign fighters into Afghanistan, something that he was involved in facilitating. ${ }^{70}$ In this example, targeted killing aimed to remove an individual who was a trusted interlocutor between distrustful elements of an insurgent group - non-Pashtun foreign volunteers and the predominantly Pashtun Taliban. There is no evidence to suggest killing al Nadji has reduced the number of foreign fighters arriving in Afghanistan, but there are a number of reasons to think it will not have done. Al Nadji will have been quickly replaced and recruits to Al-Qaeda continue to arrive in Pakistan hoping to fight in Afghanistan. ${ }^{71}$ It seems unlikely that the loss of one man would reduce the flow of foreign fighters into the country given that Jihadi groups across the world, and particularly those in Pakistan, have deep and extensive historical, and often familial and personal, links to Afghanistan.

The effect of targeted killing may be greater on smaller groups, but even then it is limited. Seamus McElwaine, a particularly violent IRA activist, was killed in 1986, setting back the IRA in the area substantially. ${ }^{72}$ A year later, the SAS ambushed and killed an entire IRA active service unit as they attempted to destroy a police station at Loughgall. ${ }^{73}$ In the years that followed the SAS killed or arrested two generations of IRA leaders in the area, those in control and those in waiting, so bad was the damage that one IRA member commented that after 1992 'that was it; we had nobody left'. ${ }^{74}$ But even this increased effect on a smaller group was limited. In 1990 the IRA destroyed the remainder of Loughgall police station, and they continued to operate in South Fermanagh and Armagh 
until the end of the troubles. ${ }^{75}$ Even today, South Fermanagh remains the area with the highest threat from dissident Republican terrorists. ${ }^{76}$

Groups may become more resilient due to the adaptations they undergo when subjected to targeted killing. Aaron Mannes' statistical assessment of Israeli targeted killing supported this analysis in finding 'The most significant...[statistical result]....an increase in the number of [violent] incidents by religious organizations after they have lost their leader for the second or third time'. ${ }^{77}$ This reduced effect is simple to understand. If a role is vital to the functioning of your organisation, and you lose that person, the effect will be significant. If this happens again, you are likely to train two people for the role, in order to have some redundancy. If over time, turnover was very high, you would try to make sure all of your staff were able to cover the role. This would be difficult if the role required in-depth technical knowledge, but few if any insurgent roles do. As such, each targeted killing has less effect than the last, as the insurgency learns to decentralise and disperses responsibilities. Al-Qaeda in Pakistan have shown just such an adaptation, with many senior leaders now having joint responsibilities for areas once assigned to individuals, making a clear hierarchy and individual specialisations difficult to discern. ${ }^{78}$

Targeted killing, when selectively employed for a discrete purpose against a specific individual can reduce the capabilities of insurgent groups, but its effects reduce with each successive use as groups decentralise command and control and disperse capabilities in response.

\section{Targeted Killing and Psychology}

Targeted killing aims to have psychological effects on insurgent groups to induce behavioural change. The intended psychological effects aim to deter insurgents from fighting, to cause dissension within groups and to divide groups. ${ }^{79}$ This section demonstrates that targeted killing does not achieve its psychological aims, shows why this is the case and demonstrates that the psychological effects are counterproductive.

The basic psychological aim of targeted killing is to make insurgents in key positions so afraid of death that they giving up fighting. ${ }^{80}$ Major General Richard P. Mills, former ISAF Commander in Afghanistan's Helmand and Nimruz Provinces, described this in May 2011 when he said that targeted killing aimed to make the Taliban 'go back to their old way of life and put the rifle down and pick up a spade'. ${ }^{81}$ Occasionally this works. Taliban commander Eidi Mohammed from Baghdis has said he ceased fighting because American operations are very effective: the 
night raids, the airstrikes and ground attacks...I was afraid they would kill me too. ${ }^{, 82}$ More often it does not. Taliban commander Mullah Yunis knows he is near the top of the US Kill/Capture list in his region of Baghlan and knows death is likely to find him soon as many of his predecessors have been killed. Yet still he leads and fights, saying if you kill us, we become stronger, and the number of our attacks will just increase as time passes'. ${ }^{83}$ The evidence supports his rhetorical claim. If insurgents were dissuaded from taking positions, there should be an extended list of vacancies in the Taliban's shadow governance and military structure. Yet, according to the consensus view of the US intelligence agencies, the Taliban are able to 're-establish and rejuvenate' often within days of a targeted killing, and a US Special Operations Force commander confirms that the insurgency takes only a few days to a few weeks to fill the gap left after a targeted killing. ${ }^{84}$ There are now more shadow governors across the country than ever before, the Taliban's military structure contains no vacant posts and covers a wider area than at any point since $2001 .{ }^{85}$ Similarly, neither the Palestinian nor the Chechen insurgencies have vacant positions in their leadership, despite the targeted killing of their leaders. ${ }^{86}$

Recruitment and retention of fighters should also be affected if targeted killing deters. This would be evidenced by a reduction in violence; but violence in Afghanistan has sustained or surpassed the high levels of 2009 throughout the stepped up targeted killing campaign in 2010 and $2011 .^{87}$ The psychological aims of targeted killing are not met because they are based on a common sense, but unscientific, understanding of psychology. Counterinsurgents employing targeted killing for psychological effect assume that human beings make purely rational decisions based on a cost/benefit analysis of a given action and that they can remotely judge what is rational to the insurgent. They therefore believe they can increase the 'cost' of fighting to a point where it outweighs the benefit of doing so, and thereby induce behavioural changes in the insurgent. This section demonstrates that this is too simplistic. Human decision-making is much more complex. The application of scientific psychological understanding shows that the psychological effects of targeted killing are counterproductive.

The idea that targeted killings deter is based on Rational Choice Theory (RCT) which holds that states and individuals make decisions based on a cost/benefit analysis, according to which they judge the best means to achieve their aims. ${ }^{88}$ But, as we have discussed, most are not deterred. Psychologist Ariel Merari notes that: 
In a perfectly rational system, the basic idea of deterrence is to deliver a clear, credible message to the opponent that the cost of pursuing a certain course of behavior outweighs its benefits. In reality, however, this simple formula rarely, if ever, works according to expectations. ${ }^{89}$

Some will be deterred but many will not. Rational decision-making in the context of insurgency is impossible to define and dependent on many factors. One cannot predict whether, in his or her mind, the cost, including the risk of being killed, will outweigh the benefit of achieving the objectives for which the insurgent fights. ${ }^{90}$ Humans tend to underestimate risks when they actively choose to expose themselves to danger. Thus the motorcyclist never believes he will die in an accident even as he acknowledges the relatively high statistical risk to motorcyclists. ${ }^{91}$ Similarly, insurgents may not judge the risks of fighting 'rationally'. Furthermore, if night raids win sympathy and support for the Taliban, as former COMISAF General McChrystal once argued, the more strategically minded and radical of the Taliban might 'rationally' accept martyrdom to advance insurgent aims. ${ }^{92}$ Additionally, an RCT based approach assumes that becoming an insurgent is a wholly rational process. It is not. The decision to join the fight is often disadvantageous to the individual, and therefore cannot be adequately explained as a purely 'rational' decision. ${ }^{93}$

Targeted killing will not entirely deter because it fails to address the causes that drive insurgents to fight. Psychological analysis has shown that insurgents fight when they have a grievance that they are unable to address. Often, this grievance is a collective complaint. So, in general terms, Nationalists in Northern Ireland wanted to be governed by Dublin not London, and the Taliban want government by the Sharia, not a democratic system. A few committed individuals will usually seek to address the grievance through local action or political participation. If their moderate action fails, their frustration leads them to adopt more radical, and ultimately violent measures. In this way they might be said to be altruistic, acting on behalf of a group desire which most are too apathetic or self-interested to sacrifice for. Insurgents, at their core, are therefore an activist fringe representing a more widely felt grievance. ${ }^{94}$ Once an insurgent group is established, it may attract the psychopathically violent, as with Abu Musab al-Zarqawi in Iraq or Johnny Adair in Northern Ireland, but in general, insurgents are socially motivated, acting on behalf of a group. Killing leaders will not deter the psychopaths, and will only further frustrate and anger the socially motivated, while winning them greater support from those who sympathise with their aims. 
To understand how the targeted killing of insurgents wins sympathy for the group, it is necessary to understand the psychological effect of targeted killing on the wider population from which the insurgents are drawn. This chapter has shown how insurgents fight for a grievance more widely felt, thus it is that General McChrystal explains how many in the population will be angered when they see a leader or insurgent targeted who they 'do not necessarily think...[was]... killed because they were doing something wrong. ${ }^{95}$ Although the Taliban are not universally popular among the Pashtun, their cause attracts wide sympathy. Consequently even those who are not active supporters, or who dislike Taliban methods do not see them as wholly illegitimate actors. Such was the situation in occupied France in World War II. Most French people were simply trying to survive under occupation, many had sympathy with both the Vichy government, which sought to ameliorate the excesses of German occupation, and with the 'extremists' of the day, the Communists, who were generally the more active resistors, but whose maximalist goals were not widely shared. When Communist violence damaged relations with the Germans or targeted Vichy supporters, their support fell, but when the Germans imprisoned, deported or, in particular, when they executed the usually young Communist fighters, sympathy and support for the resistance grew. ${ }^{96}$ This example shows the "psychological effects' of killing and capturing insurgents and the negative ramifications of the approach.

The psychological, deterrent, effect of targeted killing is reduced still further by group loyalty. Once in a group pursuing ends through violent means, the desire to belong leads to a desire to advance group aims ahead of individual ones. ${ }^{97}$ As a soldier takes a bullet for his comrades, or a protester lies down before a tank, so an insurgent can desire martyrdom. Targeted killing is unlikely to deter in the face of such socially constructed unity.

If we look to psychological studies of terrorists that have laid down their arms we can see once again that targeted killing is unlikely to deter. Such studies show that most gave up due to a change in their personal lives, such as after marrying or becoming a parent. Of the remainder, most gave up because they saw that their use of violence was losing them support and making achievement of their ends more distant. Few laid down arms out of fear and few lost their passion for the cause that they had fought for. Many that eventually walked away from terrorism claim it was the use of violence by the state that drew them in as recruits and, during their active period, sustained their belief in the need to use violence defensively. ${ }^{98}$ Targeted killing may therefore reinforce insurgent 
commitment to violence, as it wins them support and sympathy, and justifies their 'defensive' response.

Groups rarely divide, but rather unify under pressure, as danger strengthens social bonds. ${ }^{99}$ Group identities are relational, thus the group, defines itself according to characteristics that it regards as different from those who are not in the group, known as the out-group. So the British, for example, are an in-group that define certain characteristics that are different from foreigners, the out-group. Out-group pressure unifies because it allows a clearer delineation of the in-group. So England football supporters are made up of fans of Arsenal, Manchester United, Liverpool, Newcastle etc., but when faced with an opponent, say Brazil, they are united. Targeted killing is a particularly dramatic example of out-group pressure, and its unifying effect will therefore be particularly pronounced. Out-group pressure can make members of an in-group more likely to sacrifice themselves on behalf of their group. ${ }^{100}$ Belgrade's citizens, not always supporters of Milosevic, stood on bridges holding up targets during NATO air strikes, unified by attacks during the 1999 Kosovo conflict. ${ }^{101}$ Studies have shown how even strangers will risk their lives to save others in situations of danger, because the human response to danger is to unify to face an external threat. ${ }^{102}$ Another powerful unifier is shared traumatic experience. General Mills' belief that seeing an insurgent's body tossed in the back of a pickup truck dissuades villagers from joining the Taliban is unconvincing. ${ }^{103}$ Experiments have shown that shared traumatic experience bonds people together. ${ }^{104}$ Targeted killing often unifies, and psychology suggests it is unlikely to divide.

Pressure on Al-Qaeda's leadership has altered the group's structure so much that Marc Sageman felt able to describe the global movement as a 'leaderless jihad'. ${ }^{105}$ The evident isolation in which Osama bin Laden had been living in his hideout in Abbotabad, Pakistan, goes someway to support this. But though Al-Qaeda may be increasingly decentralised, it is by no means less united. In fact, since 2001, disparate Islamist groups have united under Al- Qaeda's banner in, among others, Yemen, North Africa, Central Africa and Indonesia. ${ }^{106}$ Germany, Britain and the US all now have radical Islamists, born within their borders, claiming to fight for al Qaeda ${ }^{107}$. Similar effects can be observed in Spain, Northern Ireland, and Israel. ${ }^{108}$

Targeted killing has not split the Taliban, in fact, they are now more unified within, and more unified with other groups. In mid-2008 British commander Brigadier Mark Carleton-Smith claimed that leadership targeting had created increasing fissures of stress through the whole [Taliban] organisation.... [and] ...internecine and fratricidal strife between 
competing groups' ${ }^{109}$ By the end of his Helmand command in October 2008 he withdrew this claim. ${ }^{110}$ In May 2011 General Mills claimed that targeted killing had brought the Taliban to a 'tipping point'. ${ }^{111}$ The evidence suggests he too is wrong. Kandahar residents, writers, and analysts, Alex Strick von Lindschoeten and Felix Kuehn recently confirmed earlier reports that the younger more radical Taliban are becoming ideologically and organisationally fused with Al- Qaeda. ${ }^{112}$

The Haqqani network too is increasingly indistinguishable from the Taliban. Siraj Haqqani, the youthful operational leader of the group said in interview that relations between Al-Qaeda, the Taliban and his group were excellent. Together, he said, they 'resist against the cross worshippers by cooperating with us and us with them in one trench'. He described the organisational relationship between the Haqqani network and the Taliban, claiming that fighters from both groups served under each other's leaders across Afghanistan, and that he sat on Mullah Omar's Shura Council. ${ }^{113}$

In Pakistan, the unifying effect of targeted killing is just as clear. Groups with disparate aims before 2001 have become increasingly unified since, in part in response to targeted killing by US drones, as US Ambassador Anne Patterson has noted. ${ }^{114}$ In December 200713 factions formally coalesced under the banner of the Pakistani Taliban (TTP) ${ }^{115}$ In early August 2008, Baitullah Mehsud, leader of this new coalition, was killed in a drone strike. ${ }^{116} \mathrm{He}$ was believed to be the TTP's main link to Al-Qaeda. ${ }^{117}$ US Envoy to Afghanistan and Pakistan Richard Holbrooke claimed the TTP was on the verge of splitting, now that Baitullah Mehsud, the group's 'unifying force', was dead. ${ }^{118}$ No group has split from the TTP since, but links to groups such as Lashkar-e-Taiba have grown, and in January 2011 five more groups merged with the Pakistani Taliban. ${ }^{119}$ Most worryingly, Al-Qaeda and the Pakistani Taliban are becoming increasingly inseparable. ${ }^{120}$

Targeted killing aims to create dissension, but psychology shows that out-group pressure increases homogeneity of views within the group, far from causing the dissent that the counterinsurgent/terrorist hopes to provoke. ${ }^{121}$ Unity of view accelerates the processes of group think, a process whereby groups come to distorted consensus opinions based on prevailing attitudes and/or the confidence of particularly vociferous individuals within the group. ${ }^{122}$ Studies of group think show how opinion positions have social value, and the more committed to a viewpoint an individual is, the more influence they will have within a group. Those with extreme opinions will have disproportionate influence, as holders of such views rarely balance their argument by acknowledging 
any weaknesses. ${ }^{123}$ In this way, targeted killing can aid insurgent consensus and risks radicalising insurgents further as group think clouds discussion of future tactics under a new leader, whose clarity of purpose, driven by simplistic extremism, may hold great appeal to a group unified under pressure and searching for confident direction.

Psychological studies and experiments, applied to predict the effect of targeted killing on terrorist and insurgent groups, suggest they will not break the will of the targeted group to fight, nor will they increase dissension or encourage groups to fissure. In fact their effect is likely to be to unify, increase commitment, increase radicalisation and reduce the chances of compromise.

\section{Targeted Killing and Culture}

In kinship-based societies targeted killing's counterproductive psychological effects are amplified by the need for collective revenge. This is further exacerbated by the nature of such societies in which families place members in rival organisations and institutions, such as the Taliban and the Afghan government, where they serve all the while maintaining their first loyalty to the kinship group. Since targeted killing is employed when counterinsurgents cannot find a government able or willing to arrest those targeted, most areas where the tactic is likely to be used will be in failed or failing states. Such states tend to be little developed and society governed by tribal codes and organised by local power structures based on kinship ties. ${ }^{124}$ Afghan, Pakistani, Yemeni and Somali societies are all primarily kinship based. The Afghan Pashtun provide the case study herein, but the lessons have much wider applicability.

The simple point is encapsulated in General McChrystal's COIN mathematics, which holds that killing one insurgent can create many more, because 'each one you killed has a brother, father, son and friends' who may seek revenge. ${ }^{125}$ The Pashtun tribal code, the Pashtunwali, emphasises the sanctity of the home and family as components of honour, and demands that a violation of honour requires badal or revenge. ${ }^{126}$ The Pashtun are a kinship based society so the Pashtunwali works on a collective level. Damage to the honour of one is damage to the honour of the kinship group, and requires all to work to redress the sleight. Beyond Afghanistan, similar tribal lore is found in many countries. ${ }^{127}$ General McChrystal's example could be extended to say that each insurgent killed has a family, a sub-tribe and a tribe, who may be obliged to come seeking revenge. 
In a kinship based society a father will seek the best advantage for his family by working to ensure his sons take jobs or roles in all walks of life to ensure familial influence extends as widely as possible. ${ }^{128}$ Consequently, if the family find themselves in trouble, they have a family member who can use their influence to assist. Therefore a successful kinship group will have representatives in state institutions, the Taliban, the Police, the Army, etc. While the man's sons take these roles, their loyalty to kin can trump all. ${ }^{129}$ Therefore, when a member of the Taliban whose brother is a policeman, soldier, or government official is killed, badal will require all to seek revenge for the sake of family honour. It follows then, that destabilising the insurgency destabilises society, as the clan, or kinship group seek revenge. How this works in practice in shown in two examples taken from the Communist period in Afghanistan. In August 1984 a tank in an Afghan regiment operating in Paktia province was attacked with a radio controlled mine. It rolled, killing an officer in the feared KhAD, the KGB trained Afghan Intelligence Agency. His four brothers were fighting on the opposite side, as Mujahidin, but loyalty to kin trumped loyalty to cause. The four Mujahidin brothers visited the tank regiment's Soviet adviser, asked for the name of the local Mujahidin Commander in the area where their brother was killed, and set out to take revenge. Their brother, the KhAD officer, had joined the Communist system after receiving an offer to study in the Soviet Union, which the family had accepted, seeking to extend the influence of their kinship network in both the Mujahidin resistance and the Soviet government. ${ }^{130}$ His loyalty also, would have remained first with his kin, not the state. Thus the killing of the KhAD officer, superficially a success for the Mujahidin, actually began a blood feud that destabilised the Mujahidin. Similarly, killing a Taliban member whose brother is in the Afghan police, army or government, would seem a success but would do as much to destabilise the government as the insurgency. The second example shows how cultural understanding can help to mitigate the destabilising effects of kinship loyalty. In the late 1970s, early Mujahidin rebels against Afghanistan's Communist government knew that government troops had relatives in the tribes and Mujahidin. They went to extraordinary lengths when attacking troops to prevent the government being able to invoke the need for vengeance to turn tribes against each other. They would announce attacks in advance to offer a chance of surrender, send representatives into government villages despite the risk of arrest to seek parley, and approach tribes with the dead bodies of their kinsmen, killed while serving as soldiers, to seek mediation and avert a blood-feud. ${ }^{131}$ 
The Pashtunwali places great emphasis not only on revenge, but on hospitality and asylum. ${ }^{132}$ This is again common to most kinship-based societies. ${ }^{133}$ Since hospitality extends to protecting a guest and seeking revenge on their behalf if they are harmed, killing 'foreign fighters' could widen the insurgency, as those that were hosting them seek revenge. This consequence may be further increased in cases where foreign fighters have married into local society. For example, Al-Qaeda's Egyptian leader Ayman al-Zawahiri is today married into a Pashtun tribe in the NWFP. ${ }^{134}$

In this way targeted killing can increase the overall level of violence not only by unifying and radicalising insurgent groups but also, in kinship societies, by drawing more and more people into the violence. As one analysis of Helmand province argues 'It seems clear that many Helmandis have been alienated through these operations, and have turned to the Taliban as a way to enact revenge for their lost relatives. ${ }^{, 135}$

\section{Targeted Killing and Insurgent Evolution}

Targeted killing, measured against its aims, can achieve immediate results when undertaken for a discrete purpose against a specific individual and limited short-term success in degrading capability, but is unlikely to achieve the psychological aim of reducing rebels' will to fight. The effects of its repeated use are profoundly counterproductive over the medium to long term. It forces insurgent groups to undergo a rapid evolution to survive. This evolution mitigates the effect of targeted killing, ensuring that it is subject to a law of diminishing returns in which each subsequent killing has less effect than the last on insurgent capability. The nature of this evolution is visible in all conflicts where targeted killing has occurred. Fear and paranoia leads insurgents to develop better operational security. Groups become more unified and less centralised, and thus more resilient; organisational capabilities are less concentrated in individuals. As this sectionr will show, the leadership of the group becomes younger and more radical, less inclined to negotiate, more violent and less discriminate. Groups are displaced and seek safe havens, widening the zone of instability. Frustrated locally, they become more regionally and internationally focused. Often they win support through the sense of injustice targeting killing can engender and the 'martyrs' it creates, figures of sympathy, respect and emulation. 


\section{A Younger, More Radical, Less Discriminate Insurgent}

Aaron Mannes' and Jenna Jordan's studies of targeting killing found that insurgents, particularly religiously motivated groups, became more radical and violent when their leaders were killed. ${ }^{136}$ The effect increased with each subsequent leader killed. ${ }^{137}$ Targeted killing's psychological and cultural effects increase radicalisation. These effects can be magnified as targeted killing removes older leaders, who tend to be more pragmatic, promoting a radical youthful leadership no longer restrained by their elders. This youthful leadership will often have grown up fighting the counterinsurgents and should not therefore always be miscategorised as 'inexperienced'.

In two years, the Taliban have lost an entire generation of leaders in many parts of Afghanistan. In 2010 in the north of Afghanistan, night raids reduced the average age of the Taliban leadership from 35 to $25 .{ }^{138}$ In the 12 months to May 2011 in Helmand Province, night raids achieved the same effect, reducing the average age of the Taliban leadership from 35 to $23 .{ }^{139}$ In 2001 the Taliban contained a few youthful extremists restrained by an elder leadership. ${ }^{140}$ The Taliban leadership in 2011 is younger, more radical, more violent and less discriminate than in 2001, because of targeted killing. ${ }^{141}$ This new in-country leadership have increasingly adopted Al-Qaeda's terrorist tactics and have deeper links with Al-Qaeda than their predecessors. ${ }^{142}$ In the North, Uzbek leaders, linked through the Islamic Movement of Uzbekistan (IMU) to Al-Qaeda, are increasing in prominence. ${ }^{143}$ Without targeted killing, the more pragmatic, less indiscriminately violent, leaders would remain as the killing of Mullah Sadiq demonstrates. Al-Jazeera journalist Qais Azimy met with Sadiq several times. He describes the 35-year- old as a pragmatist, noting his anger at the actions of the extremist fringe of the Taliban. ${ }^{144}$ Today, that fringe dominates the insurgency. Mullah Abdul Hakim Mujahid, a deputy leader of Hamid Karzai's peace council and former Taliban ambassador to the United Nations says that targeted killing has eliminated older pragmatic commanders and that 'the fanatical ones have come in their place ... In that way we are losing a lot of politically-minded Taliban. The new ones have a more religious mentality. They are only fighters. ${ }^{145}$ Not only are the new leadership more radical and indiscriminately violent, they are also less likely to talk. The French experience in Algeria shows the universality of this counterproductive effect. ${ }^{146}$ In Northern Ireland, credible interlocutors were not only kept alive but protected by the British state, not because they were moderates but because they were pragmatists who the British believed they could one day talk to. ${ }^{147}$ 
Taliban leader, Mullah Omar, has tried to restrain the more radical, youthful, in-country commanders. Suicide bombing was introduced and expanded against his orders. ${ }^{148} \mathrm{He}$ cannot stop the practice as this would alienate him from his increasingly extreme in-country leadership. Although perhaps convinced of the military utility of suicide bombing, it is Omar and the older, more pragmatic, conservative, Taliban leadership in Quetta, who continue to try to restrain the radicals. It is they that published the Layha, on limiting civilian casualties and carefully targeting suicide attacks against high-value military targets. ${ }^{149}$ Omar and the older leadership remain alive only because their safe haven prevents their being targeted. Without them, there would be no Lahya, no restraining hand on the more extremist fringe of the movement, and perhaps no one to negotiate with when the time comes. In Pakistan, the same evolution of insurgent groups is visible. ${ }^{150}$ The recent killing of Ilyas Kashmiri, leader of Harakatul Jihad-e-Islami (HUJI), by a CIA drone strike shows the dangers of removing older leaders. Kashmiri prevented his group from attacking Pakistani targets; now that restraint is gone. One HUJI commander witnessed:

several occasions when Pakistani militant commanders ... have tried to provoke him for not allowing his men to fight against Pakistani security forces, as they were arresting and killing his fighters and then cooperating with the Americans to eliminate him through their unmanned spy planes....Kashmiri Sahib would always turn down their suggestions and would tell them that Pakistan was a fortress of Islam and home of the brave Muslims. ${ }^{151}$

The Northern Irish, Chechen, Palestinian and Basque conflicts show the same evolution. In the late 1980s an entire generation of Loyalist leaders, mostly in their late 30s or early 40s, were killed by the IRA or arrested by the British. They had long feared the effects on Protestant communities of escalating sectarian violence in Northern Ireland, and in this sense, might be described as cautious and moderate. The generation of leaders that succeeded them were younger, more extreme and more violent. They pursued, unrestrained, their aim of 'taking the fight to the IRA', which meant, more often than not, targeting innocent Catholics. ${ }^{152}$ Targeted killing of Chechen insurgent leaders has reduced the average age of their commanders to around 40. Simultaneously, the insurgency has become more Islamist, less Nationalist, closer to global jihadi networks, and increasingly indiscriminate. Doku Umarov, who the Russians continue to try to kill, is a restraining hand on his Chechen fighters 
whose average age is $18 .{ }^{153}$ In Palestine the average age of Hamas activists and leaders, long targeted by Israel, is 30-40 while the average age of the more 'moderate' Palestinian Liberation Organisation leaders is 60-70. ${ }^{154}$ In 1960s Spain the Basque Nationalist group Euskadi Ta Askatasuna (ETA) was formed by young men frustrated by the moderate Basque nationalist stance of their fathers. ${ }^{155}$ Their campaign of violence accelerated after their leader Tsabi Etxebarrieta was killed. ${ }^{156}$

General Mills, and many of those interviewed for this study, suggest that reducing the average age of insurgent leaders reduces the leadership's experience and effectiveness. ${ }^{157}$ But a 23-year-old leader fighting in Afghanistan, Israel or Chechnya today, may have grown up fighting the counterinsurgents. IRA leader Seamus McElwaine, when he was killed aged 26, had been an effective terrorist for ten years. ${ }^{158}$ A Taliban commander aged 23 in 2011 may have been fighting ISAF since 2001, from the age of 16. His experience would all be relevant. He is not wedded to outmoded or ineffective tactics from 'the last war'. His survival is testament to his improved OPSEC (operational security) and adoption of more effective tactics. Such men cannot be described as inexperienced.

\section{Widening the Zone of Instability}

Targeted killing displaces insurgents as they seek safe havens, widening the zone of instability. Daniel Byman's studies of targeted killing in both the Israeli-Palestinian conflict and Afghanistan, argue that targeted killing drives insurgents into urban areas, where they hope to be harder to find. ${ }^{159}$ Many senior Al-Qaeda leaders have been arrested in Pakistan's urban areas, where they were trying to avoid aerial surveillance by drones. ${ }^{160}$ Their movement, along with a similar migration of the Pakistani Taliban, has destabilised large areas of Pakistan. ${ }^{161}$ In Chechnya, Russian targeted killing and security force pressure has displaced Chechen insurgents from the cities, to the mountains, forests and sympathetic towns in neighbouring provinces. ${ }^{162}$

Targeted killing often causes insurgent groups to target those they had previously left alone, or to expand the area of conflict. There has never been a Taliban bombing in the West, but for the first time, in 2011, some in the movement have declared their intent to carry out such attacks. ${ }^{163}$ Militants did not attack Pakistan before 2001, since then, it has become a target, in part in response to the CIA's target killing. ${ }^{164}$ The Pakistani Taliban are showing increasing ambitions to become a global terrorist group. ${ }^{165}$ In 2010 Faisal Shezad, linked to the TTP, attempted to detonate a car bomb in Times Square, New York. ${ }^{166}$ In 1974, the 'decapitation' of 
the IRA as a result of an intense programme of arrests led it to widen the focus for its attacks, carrying the fight to mainland Britain for the first time. ${ }^{167}$ After the SAS ambush of the IRA at Loughgall in 1987, the IRA widened its campaign further, attempting an attack on Gibraltar and planning attacks in West Germany on British military bases. ${ }^{168}$ In Chechnya, targeted killing has contributed to the insurgency's decision to attack targets across Russia. ${ }^{169}$

\section{Sympathy, Respect, Emulation}

Killing leaders creates martyrs who inspire others to emulate them. The concept of martyrdom today is primarily associated with Islamist violence, but is in fact important to all insurgent groups. In 1867, 'Martyrdom' played a key role in launching the Fenian movement, an early Irish nationalist group. Friedrich Engels commented on the execution of the Fenians by the British that there was no heroism associated with the attack until they were executed but: the 'deed ... will now be sung to every Irish babe in the cradle in Ireland, England and America'. ${ }^{170}$ It was the killing of Benno Ohnesorg that launched the secular left-wing group the BaderMeinhof gang in West Germany in the 1970s. ${ }^{171}$ Nationalist funerals in 20th century Northern Ireland were key to sustaining the IRA's popularity. Thus it was that the British banned further 'ambushes', the targeted killing of the day, in 1979 to prevent the creation of 'martyrs'. Major-General James Glover, responsible for the decision, described how the killing of IRA members led to funerals becoming 'set-piece demonstrations of solidarity in which the precise circumstances of the person's death are often forgotten as the mourners succumb to emotion'. This logic eventually persuaded many supporters of 'ambushes' to acknowledge that the effects were counterproductive. ${ }^{172}$ Nevertheless, the British renewed the 'ambush' campaign in 1983, having persuaded themselves that it was the 'precise circumstances' of the death that made it a recruitment tool for the IRA, which they hoped to mitigate by ensuring all future targeted killings were manifestly fair. It was not until 1997 that they concluded that all targeted killings had a radicalising effect, and banned the tactic. ${ }^{173}$ The Taliban too make use of martyrdom as a recruitment tool, attending the funerals of shahids (martyrs) to mobilise support. ${ }^{174}$

Islamist extremists are inspired by Hassan al-Banna, Sayyid Qutb and Abu al-A'la Mawdudi, ${ }^{175}$ as well as the more recent work of Abdullah Azzam. ${ }^{176}$ All are long dead, Banna, Qutb and Azzam were killed and Mawdudi long imprisoned but their ideas outlived them and continue to attract adherents around the World. Ed Husain, a former Islamist, writes 
of the exhilarating thrill of reading Qutb clandestinely, out of sight of his father, in the UK in the 1990s, 30 years after Qutb was hanged. In fact the death of Islamists as a consequence of their beliefs, their 'martyrdom', heightened their attraction. ${ }^{177}$ Bin Laden said 'If I live or die, the war will continue $^{178}$, he 'seeks martyrdom', because, if achieved, it would create another '1,000 Osamas'. ${ }^{179}$ It is perhaps too early to tell if he misjudged, but the precedents suggest he may be correct. Targeted killing supports the narrative of Al- Qaeda and militant Islamists, just as it did that of the IRA and militant Catholic nationalists.

\section{Why Do Counterinsurgents Fail to See the Nature of the Evolution?}

Insurgencies are bewildering societal phenomena, rooted in local complexity yet increasingly interlinked globally with groups of diverse motivation and composition. To impart understanding of such phenomena counterinsurgent intelligence staff and public commentators construct a reductive narrative of events and actors. Building on the pre-existing knowledge of their audience, they create analogies in order to define by extension and remove distinctions in order to simplify. This imparts a rapid but superficial understanding of the insurgency and general concepts, but more is obscured than revealed.

This imprecision of expression obscures targeted killing's effects by using false analogies. In one example, when targeted killing is described as a strategy of attrition, the assumption is that the insurgency is a rock or a physical thing that can be eroded. ${ }^{180}$ This description justifies 'eroding' insurgent groups by killing members to make it smaller. But an insurgency is not finite like a rock. Targeted killing can increase the membership of insurgent groups, rendering the analogy misleading. In a second example, counterinsurgents tend to anthropomorphise insurgent groups. They do so in one of two ways.

First, by subsuming the complex composition and motivation of the group in a caricature of its leader: rather than understand and explain the broad swell of sentiment that launched the insurgency, it becomes embodied in an individual, a bogeyman to be hunted and killed.

Second, the insurgency becomes a human body, and medical analogies proliferate. 'Operations' are 'surgical' and 'precise'; removing 'cancerous cells' - individuals or groups - can cure the problem; or insurgencies can be 'paralysed', 'blinded', or have their 'eyes and ears' removed. ${ }^{181}$ However, an insurgency is not a human body. Counterinsurgents cannot 'diagnose' the cause of something so complex, and, in treating the 
symptoms they often exacerbate, not cure, the affliction. Targeted killing is, in part, a product of the human desire to categorise and simplify. Understanding by comprehension, not extension is required, which is dependent on exactitude of language. ${ }^{182}$

It might be argued that the language used does not matter, on the basis that the analogies are used by those who have reasoned the problem through coherently to rapidly explain their concept to others. But the way a case is presented affects the interpretation of it, and has dangerous real world effects. Psychologists have shown how inaccurate use of language insidiously alters human comprehension and beliefs, and thus behaviour. ${ }^{183} \mathrm{~A}$ cross-section of voters who supported 'inheritance tax' in one survey were against 'death taxes' in another, despite the detail being the same. ${ }^{184}$ Linguists demonstrate how some words can think for us, bypassing the critical examination that would result from a more accurate description. ${ }^{185}$ US Major General Timothy McHale, investigating the killing of 23 Afghan civilians by ISAF in February 2010, found the use of inaccurate language to be an important part cause of the tragic, avoidable, error. ${ }^{186}$ The abuses at Abu Ghraib were facilitated by the way in which language was used. ${ }^{187}$ The military description of the killing of insurgent leaders by bombing as 'kinetic strikes' or KS hides the reality behind pseudo-scientific, politically acceptable and ethically neutral language. The way we describe things affects our attitudes and beliefs, and thus our behaviour, towards them. In the case of targeted killing, language has served to obscure its counterproductive effects through the use of misleading analogies.

The desire for clarity and simplicity is also manifested in an over-reliance on abstract modelling of insurgent groups, primarily Social Network Analysis (SNA). ${ }^{188}$ SNA allows relationships to be graphically
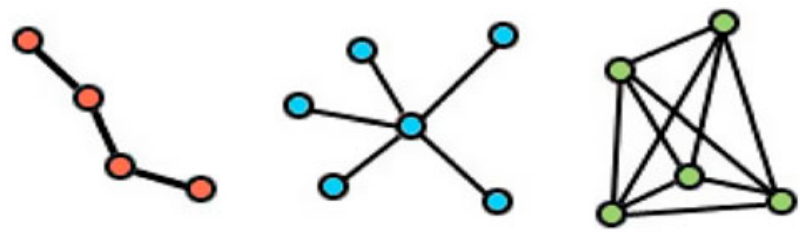

FIGURE 1. CHAIN, HUB AND ALL-CHANNEL NETWORKS

Source: John Arquilla and David Ronfeldt (editors), 'Networks and Netwars: the Future of Terror, Crime and Militancy, RAND 2001. http://www.rand.org/pubs/ monograph_reports/MR1382.html 
represented (Figure 1) describing groups in an objective, dispassionate, and scientifically verifiable manner that has intuitive appeal. ${ }^{189}$

Targeted killing is often justified by the display of a social network chart before and after a targeted killing in order to explain how the group fragmented. This conclusion ignores the fact that most insurgent networks are 'all-channel' as above, and so should be able to re-establish immediately. The illusion that they fragment is based on the acceptance of the abstraction as reality. We have noted that targeted killing can improve the OPSEC of insurgent groups. Therefore, in the aftermath of a targeted killing less trust would be exhibited in acquaintances, and insurgents will limit their communication or use other means, such as couriers or clandestine meetings, that are less easy to monitor. A network chart will show only that there are no intercepted communications or no further reports on links between individuals. It does not show the more complex reality, but rather a simplistic and incomplete abstraction. Think of your own 'social network'. Perhaps you have a group of friends with whom you have lost touch. You still hear about them through one friend, who remains in contact with you and them. If this individual were killed, how difficult would you find it to re-establish the link with your old friends? Imagine you alter your behaviour after the killing and do not contact friends via the telephone. Your network has not been fragmented, but it would appear so on a chart. Further, you need not have any pre-existing links to an individual to make contact with them. A study of women seeking an abortionist in the US when abortion was illegal found that the women were able to quickly make contact through making educated guesses as to who to ask, 2.8 being the average number of guesses required. ${ }^{190}$ Similarly, insurgents would have no problem establishing, maintaining or re-establishing contacts when a 'link' to another is killed.

It is important to remember that such charts are based on intelligence. The picture presented is at best partially accurate. The abstractions built from such information obscure the uncertainty on which they rest. SNA has proved a poor predictor of behaviour when used to assess peoples' shopping habits online and to send them targeted marketing of items they are likely to buy, running at a predictive error rate of over 90 per cent. ${ }^{191}$ If SNA is a poor predictive tool when information is rich and reliable, it is likely to be poorer still when based on intelligence reports. Social network diagrams give a false impression of success that is not supported by more reliable indicators such as levels of violence, the complexity of attacks, levels of support for the insurgency, the geographic spread of 
violence, or the attitude of the in-country public and politicians towards the tactic.

The counterproductive effects of targeted killing have been obscured by politicians' desire to reduce the cost of fighting while still being seen to be taking action. Opinion polls in the US and Israel show that popular opinion supports targeted killing, even if they believe it makes them more likely to be attacked. ${ }^{192}$ Popularity seeking politicians may therefore support targeted killing, giving insufficient consideration to its counterproductive effects. The killing of Osama bin Laden boosted President Obama's popularity in the US considerably, though whether it contributes to making America safer is unclear. ${ }^{193}$

Targeted killing appeals to the military, because, as Stephen Grey has argued, the military has an instinctive preference for action. ${ }^{194}$ It took years of fighting militants on the North-West Frontier of British India, before Britain abandoned its preference for action in favour of 'masterly inactivity', acknowledging that co-option, bribes and defending territory, were more effective than the punitive action of 'Butcher \& Bolt'. ${ }^{195}$ Similarly, in Northern Ireland, every policy prescription, from killing terrorists to mass imprisonment, was tried before a policy of defensive policing was adopted and Britain declared that there was 'nothing weak about deliberate inactivity'. ${ }^{196}$ Institutional memories are short, and there is no evidence that these past examples have been considered in developing current policy.

The military also finds targeted killing appealing because it provides a metric of success in conflicts that are otherwise full of intangibles. Individuals can be listed in advance and killed or captured Consider the US's pursuit of former Baathist officials pictured on the playing cards handed out in Iraq. In a swirling insurgency to which they were largely irrelevant their death or capture did little or nothing to reduce the growing violence, yet their killing or capture became a focus of media, military and political attention, because it gave the appearance of measurable, tangible, progress. ${ }^{197}$ The same effect is apparent in the periodic announcement of the killing of 'key' insurgents in Afghanistan and Pakistan. ${ }^{198}$ The problem, as this study makes clear, is that in fact the success is limited, short-term and largely illusory, obscuring the tactic's counterproductive effects. More individuals will be added to bottom of the kill/capture list than will be removed from the top, as targeted killing draws more people into the insurgency.

Periods of financial austerity and public and political casualty aversion lead to the utility of military intervention as a foreign policy tool being questioned. In such periods, institutional interests lead the military to 
find a politically appealing alternative to large-scale intervention. Under such conditions in the late 20th century, the military advocated for the Revolution in Military Affairs (RMA), which, as with previous panacea, promised rapid and inexpensive victory through the application of technology. Targeted Killing's parallels with the RMA are illuminating. The RMA's 'Neo-Cortical Warfare' claimed that precision and 'information dominance' would allow the military to win with minimal bloodshed and financial cost, by manipulating the psychology of an adversary's leaders. The Neo-Cortical Warrior would use exemplary violence to induce fear and paralyse their adversaries' decision-making or cause them to behave as the Neo-Cortical Warrior desired. ${ }^{199}$ Kosovo and the 21 st century conflicts in Iraq and Afghanistan have discredited such notions, and led to their being formally abandoned. ${ }^{200}$ Ironically, as the West withdraws from the conflicts in Iraq and Afghanistan, advocates of targeted killing claim that their cheap, bloodless solution has exemplary, fear-inducing psychological effects. Targeted killing's appeal as a cheap way of fighting, that wins politicians popularity, provides the military with a basis for demanding continued funding, and keeps the military at the forefront of foreign policy, obscures the nature of the counterproductive effects the policy has in practice.

\section{Counterarguments}

In this final section I examine the case studies used in the counter-argument to the suggestion that targeted killing is of limited utility. I then consider the conclusions and suggestions of other critics of targeted killing.

When successful 'decapitation strategies' are cited, they consistently focus on Guzman, of Peru's Shining Path, and Abdullah Ocalan, of the Kurdish PKK. ${ }^{201}$ In both these cases, decapitation was by arrest, not targeted killing. In both examples, the leader called on his followers to put down their arms, leading to a dramatic collapse in the group's effectiveness. In both examples, the underlying causes of the violence went unresolved, and the groups eventually returned to violence.

Occasionally cited are the decapitation of the Philippine Abu Sayyaf splinter of the Moro Liberation Front, the Angolan UNITA, and the Sri Lankan LTTE. ${ }^{202}$ When Abdurajik Abubakar Janjalani, leader of the Abu Sayyaf group was killed, the network became a vast criminal enterprise. The group is still active, and seems to be moving back to its ideological struggle. $^{203}$ The LTTE lost internal support from many Tamils for its human rights abuses and forced conscription of children. This, and the 
Sri Lankan government's ability to take and hold land the LTTE had controlled, led to their defeat; yet even now the grievances that led to conflict remain unaddressed, and without a political solution, reports suggest the Tamils may well adopt terrorist tactics once more. Leadership targeting played a peripheral role, if any, in bringing the LTTE to defeat. $^{204}$ UNITA was already on a path to peace, had handed over territory to the government, negotiated a gradual return to parliamentary democracy and, as with many case studies, had been more weakened by political engagement than it ever had been by military pressure. The killing of Jonas Savimbi and his deputy allowed the government to agree a political solution based on accords previously signed with Savimbi but never fully implemented. Thus his killing did contribute to peace, but not by deterring UNITA from fighting, but because the Government was unwilling to address the underlying causes until his death due to their personalisation of the conflict. ${ }^{205}$

Three other examples receive occasional citations: that of the Red Army Faction in Germany, Rohanna Vijeweera, of the Sri Lankan Janathā Vimukthi Peramuna (JVP), and Fathi Shikaki, of Palestinian Islamic Jihad (PIJ). ${ }^{206}$ The Red Army Faction's leaders were imprisoned, not killed, and committed suicide, which would clearly have different effects on the remaining members of the group than their being 'martyred.' The group nevertheless continued until $1998{ }^{207}$ Rohanna Vijeweera's killing was not the end of the JVP, though there were many premature predictions that it would be. Today the JVP is 'perhaps the most resilient, dynamic and deeply-rooted political force in contemporary Sri Lanka'. ${ }^{208}$ PIJ retaliated following Fathi Shikaki's killing with a double suicide bombing against Israeli settlers in Gaza, and another a year later in Tel Aviv. The fall in support for PIJ after Shikaki was killed was caused largely by the growth of the peace process, the Palestinian Authority's clamp-down on other militant groups, and the growth of Hamas as the main rivals to the PA. By 2002, however, as the Peace Process collapsed, PIJ had fully recovered. ${ }^{209}$

In a review of 89 insurgencies, RAND found that targeted killing was not among the factors leading to insurgent defeat, while RAND's study of 648 terrorist groups found that military force rarely brought an end to them. ${ }^{210}$ In two thorough studies of 'How Terrorism Ends', neither Audrey Cronin nor Martha Crenshaw finds an example of targeted killing ending a terrorist or insurgent group. ${ }^{211}$ Concerned with a lack of balance in my study in its later stages, I turned to respected terrorism expert the late Professor Wilkinson of the University of St Andrew's Centre for the Study of Terrorism and Political Violence in search of a counterexample. 
He suggested the French group Action Directe, but noted that their entire leadership were arrested in an audacious raid rather than killed. Had they been killed, he said, the radicalising effect would probably have prolonged the organisation's existence. ${ }^{212}$ There is no example of a 'decapitation' strategy by targeted killing ending a conflict, or providing the tipping point for the conflict's end.

\section{Learning from Others}

UN Special Rapporteur on Extrajudicial, Summary and Arbitrary Executions, Philip Alston's primary criticism of targeted killing is the opaqueness of the process whereby people are designated as targets, judged deserving of death, and killed. ${ }^{213}$ If there is one action that would serve to add much needed legitimacy to the tactic, it would be to respond to this criticism by making the process open and transparent. The Israeli experience shows that this is achievable, and perhaps, desirable. The Israeli Supreme Court verdict on the legality of targeted killings in 2005 found the tactic to be legal, but insisted on regulating the processes surrounding it. $^{214}$ The court insisted that targeted killing must be a highly selective operation, which, applied to the British and US militaries, would rule out their participation in ISAF-style 'industrial scale' leadership targeting; in light of the findings regarding targeted killing's diminishing effects with each repetition, this would also ensure the tactic is used to its maximum utility.

The court also insisted that the selection of the target must be transparent, the justice of the killing immediately apparent and that a full and open investigation should be carried out immediately after the operation to ensure it was conducted appropriately. ${ }^{215}$ Israel usually seeks arrest before carrying out a targeting killing, and has often handed a list of wanted militants to the Palestinian Authority before proceeding. ${ }^{216}$ Many militants handed themselves in to the Palestinian Authority when informed that the choice was arrest, being killed or going on the run. ${ }^{217}$ This transparency aids in showing targeted killing to be just. If practised in Afghanistan, it would also help to avoid errors, allowing those targeted to give themselves up or to challenge the suggestion that they are involved in the insurgency. Perhaps the killing of Afghan notable Zabet Amanullah, which may have been a case of mistaken identity, could have been avoided if the intention to target him had been announced. Amanullah was a well-known former Taliban member (prior to 2001) who had been living peaceably in Kabul. If his name had been released before the attack, this well-known figure could have handed himself in to 
prove his innocence, had his name cleared quickly by those that knew him, or gone into hiding. In the latter case, the desired effect of targeted killing would have been achieved: the individual would have been effectively removed from the insurgency. If the effects desired by the counterinsurgent who would undertake targeted killing are to induce behavioural changes in the insurgent, they can be achieved non-kinetically, while enhancing the legitimacy of the targeted killing if the insurgent in question is found.

When the justice of targeted killings is immediately apparent, its radicalising effect is reduced. This was a lesson learned by the British in Northern Ireland, where 'ambushes', where everyone involved knew the targeted insurgents would die, had to meet the standard of the 'clean kill', to which the SAS always aspired. ${ }^{218}$ A clean kill was one achieved when the terrorists were armed and on the way to an operation. In legal terms, they would be 'Directly Participating in Hostilities', and the fact that they were armed meant they constituted a direct and imminent threat to life. It was not necessary to issue a challenge, namely to give them a chance to surrender, as doing so would increase the risk to life of the SAS soldiers and others in the area. The clean kill was a concept recognised implicitly by the IRA, and the natural justice involved would be instantly recognisable to all observers, regardless of their sympathies for the participants in the conflict. The 8 May 1987 killing of an entire IRA cell at Loughall is a good example, said to be 'the apotheosis of the clean kill', having met all the above criteria, even IRA leader Gerry Adams acknowledged in his instant reaction 'I believe that the IRA volunteers would understand the risk they were taking. ${ }^{219}$ When targeted killing takes place, ensuring the immediate and readily apparent legitimacy of the operation limits its radicalising effect.

\section{Conclusion}

Shisha ke maida shod, tiztar misha

(Broken Glass Becomes Sharper)

Hazara Proverb

Targeted killing, used highly selectively and with a transparent targeting process, can be of tactical use, temporarily reducing insurgents' capability, and disrupting facilitation networks and leadership structure. It does not follow that a repeated use of targeted killing will cause a greater reduction in insurgent capability. Insurgent networks adapt in response to targeted killing, changing structure and dispersing capability to ensure their 
resilience. Furthermore, targeted killing radicalises. Its effect on insurgent groups is to unify and reduce dissent, precisely the opposite of the psychological effects the counterinsurgent intends. Some will be deterred, but a greater number will seek revenge and in kinship-based societies this will destabilise government and security structures. Overall, the evolution that targeted killing forces insurgent groups to undergo is profoundly counterproductive. It often draws in recruits in search of revenge resulting in larger groups, consolidates alliances between disparate radicals, widens the zone of instability as the groups seek new safe havens, and risks regionalising or internationalising previously local conflicts. It brings to the fore a younger leadership, who are usually more radical, indiscriminate and violent than those they replace. They preside over groups that are both more resilient and united as a result of targeted killing.

Counterinsurgents have failed to fully appreciate the counterproductive effects of targeted killing because they offer political and bureaucratic utility to politicians and the military alike. The true effects are further obscured by a lack of true comprehension of the situation among intelligence staff, the use of simplistic analogies and the misuse of, and reliance on, SNA as a means for judging success or failure.

In an insurgency being driven by short political timescales, as in Afghanistan, targeted killing may serve policy, used as a line of operation in support of others. As it accelerates the insurgency's radicalisation and use of more indiscriminate violence, the population may seek the government's protection, while the senior leadership in exile may be encouraged to negotiate for fear of losing support from the population and losing control of the insurgency to the radical in-country operational leadership. The great risk of this tactic is that if it fails it will leave a more radical, more indiscriminate insurgency, with wider regional and global aims, and deeper links to Al-Qaeda than ever before. In Afghanistan, given that the coalition's 2001 aim was to expel Al-Qaeda from Afghanistan, leaving Afghanistan with the Taliban and Al-Qaeda indistinguishable would be a very visible failure of targeted killing specifically and coalition policy in Afghanistan more broadly.

Several clear policy recommendations emerge from the analysis: Targeted killing must be the exception not the rule; it becomes less effective with each successive use. The process behind the identification of individuals for killing must be transparent and accountable. The list of names should be published in order to enable objections to be raised, avoiding errors, and to give the insurgent the chance to surrender to arrest. If this results in the individual going into hiding, so much the better, the desired effect, rendering the insurgent ineffective, has been 
achieved without the counter-productive effects associated with killing key insurgents. The watchwords must be transparency, accountability and selectivity. The burden is on those killing to demonstrate the legitimacy and fairness of their procedures, and the efficacy of the tactic. Analysts must be careful in their use of language and conscious of the limits of their knowledge and analytical tools. Finally, the military must recognise that 'masterly inactivity' is not weak, and may bring more advantage than actions designed to remedy symptoms, the cause of which is little understood.

This study finds targeted killing is a largely ineffective, and worse, often actively counterproductive tactic in COIN. This is because, as the then Air Marshal Charles Portal argued in relation to the punitive use of airpower in Aden in 1934-35:

This method of 'bomb and scuttle' fails because its user has given too little thought to the vital question 'what is the object of the operation?' Surely the object of all coercive police action is to bring about a change in the temper or intention of the person or body of persons disturbing the peace. I would ask you to dismiss once and for all from your minds any idea that Air Force police work consists in immediate bombing as a mere punishment for misbehaviour. ${ }^{220}$

Herein lies the crux of the matter: targeted killing aims to cause insurgents or terrorists to refuse leadership positions, and ultimately to give up through fear of being killed, while also discouraging support for their cause, which will be shown to be hopeless by a ruthless and unrelenting strategy of killing leadership figures and effective facilitators. The object of the operation is to alter the 'temper or intention of the person or body of persons disturbing the peace'. It fails because it is based on frozen abstract representations of the society and groups it targets, assuming that the removal of a 'node' will fragment a group significantly, a false assumption, as I have shown. It fails because it assumes that a terrorist or insurgent group can be simply terrorised into submission, when the evidence shows that humans respond to fear by innovating, seeking revenge and uniting. It fails because psychology is not wholly based on rational calculations of survival and personal advantage. Fundamentally, it fails, in Portal's words, because 'success, and the absence of subsequent ill-will, must depend on there being no sense of injustice. ${ }^{221}$ As Alexander's armies in Afghanistan struggled to defeat the Afghan 'Hydra', so NATO today finds itself facing an enemy that grows new heads every time one is removed. As the Hazara proverb holds 'broken glass becomes sharper'. It cannot be ground into dust unless a policy of extermination is pursued; the current policy fragments 
insurgents into smaller, sharper fragments, ever harder to detect. In doing so, it is demonstrating that targeted killing, unless used highly selectively and transparently, with awareness of its counterproductive side effects and diminishing returns, does not work.

\section{NOTES}

1 Plutarch, The Fortunes of Alexander (New York: Loeb 1936) Loeb Classical Library Edition.

2 Ralph Epstein, 'Afghan Strategy Wrong, Says UK Envoy', Sydney Morning Herald, May 27 2011, <www.smh.com.au/world/afghan-strategy-wrong-says-uk-envoy-20110526-1f6fb. html> (accessed May 29 2011); Brigadier Mark Carleton-Smith, former Commander Task Force Helmand, interview by Keith Dear, March 8 2011, Emma Graham-Harrison, 'NATO's Afghan Night Raids Come With High Civilian Cost', Reuters, February 24. 2011, < http://uk.reuters.com/article/2011/02/24/us-afghanistan-raids-idUKTRE71N15U20110

224> (accessed May 29 2011); Deborah Haynes, 'Special Forces take out up to 6 Taleban targets a day, say Petraeus', The Times, September 23. 2010.

3 Kathy Gannon, I is for Infidel: From Holy War to Holy Terror: 18 Years Inside Afghanistan (New York: Public Affairs 2005) pp.109-25; Gretchen Gavett, 'What is the Secretive US "Kill/Capture" Campaign?' PBS Frontline, May 10 2011, <www.pbs.org/wgbh/pages/ frontline/kill-capture/what-is-kill-capture/> (accessed June 6 2011); Gen. David Petraeus, interview by PBS Frontline, January 29. 2011; Matthew Green, 'Petraeus orders care over Afghan night raids', Financial Times, December 17. 2010, <www.ft.com/cms/s/0/ 2356fa76-0a06-11e0-9bb4-00144feabdc0.html\#axzz1NjCb2LZw>. (accessed May 29 2011); Spencer Ackerman, 'US Commandos Can Raid Afghan Homes - And Ask Permission Later', Wired - Danger Room, April 9 2012. <www.wired.com/dangerroom/2012/ 04/night-raids-still/ (accessed September 20. 2012).

4 Rob Evans, and Richard Norton-Taylor, 'RAF "relying" on drones in Afghanistan', Guardian, February 7. 2010, <www.guardian.co.uk/uk/2010/feb/07/raf-drones-afghanistan> (accessed June 6 2011); Rajiv Chandrasekaran, 'US deploying heavily armored battle tanks for first time in Afghan war', Washington Post, November 19. 2010, <www.washingtonpost.com/wpdyn/content/article/2010/11/18/AR2010111806856.html? hpid=topnews\&sid=ST2010111806890 (accessed June 11 2011); S. Ackerman, 'Drones Surge, Special Ops Spike In Petraeus Campaign Plan', Available at http://www.wired.com/dangerroom/2010/08/petraeus-campaign-plan/ August 18 2010); Noah Shachtman, 'Afghan Ultraviolence: Petraeus Triples Air War', Wired: Danger Room, December 14. 2010, <www.wired.com/dangerroom/2010/12/afghan-ultra-violence-petraeus-triples-airwar> (accessed June 11 2011).

5 Bill Roggio, 'CIA to target AQAP in Yemen with Predators and Reapers', The Long War Journal, June 14 2011, <www.longwarjournal.org/threat-matrix/archives/2011/06/cia_to_ target_aqap_in_yemen_wi.php> (accessed June 27 2011); New America Foundation, 'Counter Terrorism Strategy Initiative', New America Foundation, Statistic: http://counterterrorism.newamerica.net/drones/2011 (accessed September 26. 2012).

6 Marie Colvin, 'Special forces assassins infiltrate Taliban stronghold in Afghanistan', The Times, February 7. 2010, < www.timesonline.co.uk/tol/news/world/afghanistan/article7017921.ece (accessed June 6 2011) >; Evans and Norton-Taylor (note 4); Chris Cole, 'We mustn't ignore the fact that British drones kill too', Guardian, May 13 2011, <www.guardian.co.uk/commentisfree/2011/may/13/britains-military-open-people-killeddrones (accessed June 6 2011) >.

7 Paul Wood, 'Night raids dog Nato's Afghan operation', BBC News, April 14 2011, <www.bbc.co.uk/news/world-south-asia-13038532> (accessed June 7 2011); Giles 
Dorronsoro, Afghanistan: The Impossible Transition, Carnegie Papers (Washington DC: Carnegie Endowment for International Peace 2011) pp.3-4.

8 William B. Connolly, The Terms of Political Discourse. 3rd ed. (Princeton UP 1993) p.10.

9 John MacKinlay, The Insurgent Archipelago (London: C. Hurst 2009) pp.4-42

10 Carlos Marighella, 'Mini-manual of the urban guerilla', Latin American Studies, June 1969, <www.latinamericanstudies.org/marighella.htm> (accessed July 2 2011).

11 MacKinlay (note 9) p.5.

12 William F. Owen, 'Seek and Destroy: The Forgotten Strategy for Countering Armed Rebellion', Infinity Journal (Spring 2011), www.infinityjournal.com (accessed June 26, 2011); A.E. Stahl, and William F. Owen, 'Targeted Killings Works', Infinity, no. Autumn (2010) pp.10-13; Kenneth Anderson, Targeted Killing in US Counterterrorism Strategy and Law (Washington DC: Brookings Institute, May 11 2009); David Kilcullen and Andrew Exum, 'Death from Above, Outrage from Down Below', New York Times, May 17 2009; Aaron Mannes, 'Testing the Snake Head Strategy: Does Killing or Capturing its Leaders Reduce a Terrorist Group's Activity?' Journal of International Policy Solutions 9 (2008).

13 Mannes (note 12); Alex Wilner, 'Measuring Coercion and Deterrence in Counterterrorism and Counterinsurgency', Studies in Conflict and Terrorism 33/4 (April 2010); Mohammed M. Hafez and Joseph M. Hatfield, 'Do Targeted Assassinations Work? A Multivariate Analysis of Israel's Controversial Tactic during the Al-Aqsa Rising', Studies in Conflict \& Terrorism 29 (2006) pp.359-82; Jenna Jordan, 'When Heads Roll: Assessing the Effectiveness of Leadership Decapitation', Security Studies 18 (2009) pp.715-55.

14 Raffaello Pantucci, 'Deep Impact: The Effect of Drone Attacks on British Counter-Terrorism', RUSI Journal, (2009) 154/5

15 Robert Fisk, The Great War for Civilisation: The Conquest of the Middle-East (London: Harper Perennial 2006) pp.125-8; Kenneth Anderson, 'Predators over Pakistan', The Weekly Standard, March 8 2010; Owen (note 12).

16 Peter Bergen and Katherine Tiedemann, 'The Drone War', New America.net/The Republic, June 3 2009, <www.newamerica.net/publications/articles/2009/drone_war_13672> (acc essed June 3 2011); Kilcullen and Exum (note 12).

17 Owen (note 12).

18 Anderson (note 12) pp. 23-5; Jane Mayer, 'The Predator War', New Yorker, October 26. 2009, <www.newyorker.com/reporting/2009/10/26/091026fa_fact_mayer> (accessed March 6 2011).

19 Eric Schmitt, 'Confrontation in the Gulf; Air Force Chief is Dismissed for Remarks on Gulf Plan; Cheney cites Bad Judgment', New York Times, September 18. 1990, < www.nytimes.com/1990/09/18/world/confrontation-gulf-air-force-chief-dismissed-for-remarks-gulf-plan-cheney-cites.html> (accessed June 3 2011).

20 Ibid.

21 Mayer (note 18).

22 Siobhan Gorman, 'CIA Had Secret Al Qaeda Plan: Initiative at Heart of Spat With Congress Examined Ways to Seize, Kill Terror Chiefs', Wall Street Journal, July 13 2009, <http://online.wsj.com/article/SB124736381913627661.html> (accessed June 14 2011). Joby Warrick, 'CIA Assassin Program Was Nearing New Phase: Panetta Pulled Plug After Training Was Proposed', Washington Post July 16 2009, <www.washingtonpost.com/ wp-dyn/content/article/2009/07/15/AR2009071503856.html> (accessed June 14 2011).

23 US Army and US Marine Corps, Counterinsurgency Field Manual (FM3-24)(London: Univ. of Chicago Press 2007) p.193 and pp.317-29.

24 Anatol Lieven, Pakistan: A Hard Country (London: Penguin Books 2011) p.458.

25 Jules Stewart, Britain and the North West Frontier: Strategy, Tactics and Lessons (Washington DC: Jamestown Foundation 2009) p.9.

26 Lieven (note 24) pp. 99, 380, 434.

27 Sana Haroon, Frontier of Faith: Islam in the Indo-Afghan Borderland (London: Hurst 2007) pp.138-9; Lawrence James, The Rise and Fall of the British Empire (London: Abacus 1998) pp.562, 567. 
28 Spencer Ackerman, 'Drones Rejoice! Petraeus to Head CIA, Panetta to Pentagon', Wired - Danger Room, April 272011.

29 MOD, 'The Strategic Defence and Security Review', direct.gov. Oct 2010, 8; Royal Air Force, 'RAF Announces New Reaper Squadron', Royal Air Force, May 13 2011. <www.raf.mod.uk/news/archive/new-reaper-squadron-13052011> (accessed May 30 2011).

30 CNN, 'US Airstrikes in Pakistan called "very" accurate', CNN, May 18 2009, <http:// edition.cnn.com/2009/POLITICS/05/18/cia.pakistan.airstrikes/> (accessed May 31 2011) ; S. Ackerman, 'Shadow War in Yemen Could Heat Up After "Printer Bomb" Scare', Wired - Danger Room. December 1. 2010. http://www.wired.com/dangerroom/2010/11/ shadow-war-in-yemen-could-heat-up-after-printer-bomb-scare/ (accessed May 31 2010); Theresa May, 'Home Secretary's speech on Terrorism in Full', Politics, November 3. 2010, <www.politics.co.uk/features/legal-and-constitutional/theresa-may-speech in full\$21385369.htm> (accessed March 21 2011); Julian E. Barnes and Adam Entous, 'Yemen Covert Role Pushed', Wall Street Journal, November 12010 , $<$ http://online.wsj.com/article/SB10001424052748704477904575586634028056268.html? mod=ITP_pageone_0> (accessed 3 June 2011); Roggio (note 5); (Shinn, Defining Al Qaeda's Center of Gravity: Ideology, Population, and Safe Havens. The Changing Strategic Gravity of al Qaeda. (Wshington D.C.: The Jamestown Foundation, 2009) 2009); Paul Wood, 'Night raids dog Nato's Afghan operation', BBC News, April 14 2011, <www.bbc.co.uk/news/world-south-asia-13038532> (accessed June 7 2011).

31 DeYoung and Pincus, 'Success Against al-Qaeda Cited', Washington Post, September 30 2009, available at http://articles.washingtonpost.com/2009-09-30/news/36842955_1_ qaeda-al-qaeda-counterterrorism-effort (accessed 25 Oct 2013)

32 Celeste Ward, 'The Pentagon's Obsession With Counterinsurgency', Washington Post Online, May 17 2009, <www.washingtonpost.com/wp-dyn/content/article/2009/05/15/ AR2009051502069.html> (accessed June 29 2011).

33 Robert Haddick, 'This Week at War: End of the COIN Era?' Small Wars Journal, June 23 2011, <http://smallwarsjournal.com/blog/2011/06/this-week-at-war-end-of-the$\mathrm{co} / \# \mathrm{c} 021549>$.

34 David E. Sangar and Eric Schmitt, 'Between the lines an expansion of drone strikes in Pakistan', New York Times, December 1. 2009, www.nytimes.com/2009/12/02/world/asia/ 02strategy.html (accessed June 6 2011).

35 Jim Garamone, 'Commanders Re-balance Strategy in Afghanistan', US Dept. of Defense, December 8. 2010, <www.defense.gov/news/newsarticle.aspx?id=62002> (accessed June 3 2011); Kiran Stacey, 'UK special forces Afghan role after 2014', Financial Times, May 20 2012, <www.ft.com/cms/s/0/fa8d2a98-a275-11e1-826a-0144feabdc0.html\#axzz24pfy6DMd>.

36 Gen. (Ret.) B. B. Bell, 'General Bell: If Not There, Where? - And Response'. The Chattanoogan, June 27 2011, <www.chattanoogan.com/articles/article_204087.asp> (accessed June 28 2011); Owen (note 12); Peter L. Bergen, The Longest War: The Enduring Conflict between America and Al-Qaeda (New York: Free Press 2011) p.313.

37 Air Marshal Chris Nickols, Chief of Defence Intelligence, interview by Keith Dear (June 8 2011); Air Commodore Andrew Turner, Assistant Chief of Staff (Plans) to Commander Joint Operations, interview by Keith Dear (June 7 2011); Col. Roni Amir, Head of Doctrine, Israeli Air Force, interview by Keith Dear (May 31 2011); Brig. Mark Carleton-Smith, former Commander Task Force Helmand, interview by Keith Dear (March 8 2011).

38 Mayer (note 18); Gp. Capt. Afie Ashraf, Joint Terrorism Analysis Centre, UK MOD, interview by Keith Dear (July 12 2011); Amir (note 37); Name withheld, Pakistani military officer, interview by Keith Dear (June 6 2011).

39 Bergen (note 36), 332-3; Bergen and Tiedemann (note 16).

40 Ibid.

41 Bergen (note 36) pp.202-3.

42 Ibid.

43 Ibid. pp.247-8. 
44 Thomas Hegghammer, The Failure of Jihad in Saudi Arabia. (West Point, NY: Combating Terrorism Center 2010) p.6.

45 Marc Sageman and Bruce Hoffman, 'Does Osama still call the shots? Debating the containment of al Qaeda's leadership', Foreign Affairs, July/Aug. 2008; Richard Norton-Taylor and Owen Boycott, "Mumbai-style" terror attack on UK, France and Germany foiled', Guardian, September 29. 2010; Bruce Riedel, Deadly Embrace: Pakistan, America, and the Future of Global Jihad (Washington DC: Brookings Institution 2011) p.99.

46 Shashank Joshi, 'Afghanistan heads towards a messy, unresolved stalemate', Daily Telegraph, September 19. 2012, http://blogs.telegraph.co.uk/news/shashankjoshi/100181834/afghanistan-heads-towards-a-messy-unresolved-stalemate/ (accessed September 20 2012).

47 US Army and US Marine Corps (note 23).

48 Austin Long, 'Predator Vs Weber in South Asia', Foreign Policy: AFPAK Channel, 31 Aug. 2009 , < http://afpak.foreignpolicy.com/posts/2009/08/31/predator_vs_max_weber_in_sou th_asia (accessed July 4 2011) >, p.1.

49 Jordan Jones, 'Taliban Burn Mosque, Leaders Captured, Killed', NATO ISAF Press Releases, December 19. 2010, <www.isaf.nato.int/article/isaf-releases/taliban-burn-mosque-leaders-captured-killed-2.html > (accessed June 2 2011).

50 Joby Warrick and Peter Finn, 'CIA director says secret attacks in Pakistan have hobbled al-Qaeda', Washington Post 18 Mar 2010. Available at http://www.washingtonpost.com/ wp-dyn/content/article/2010/03/17/AR2010031702558.html?sid=ST2010031703003

51 Michael Hart, Former Chief ISAF J2, interview by Keith Dear (March 31 2011).

52 Anthony Loyd, 'Taliban fighters may be granted amnesty under an Afghan reintegration plan', The Times, October 25 2010. Available at http://www.theaustralian.com.au/news/world/taliban-fighters-may-be-granted-amnesty-under-an-afghan-reintegration-plan/story-e6frg6so-1225943066161

53 Ibid.

54 Ibid.

55 Anand Gopal, 'Who are the Taliban', Blog Post 4 Dec 2008. Available at http://anandgopal.com/who-are-the-taliban/ Steve Hynd, 'Taliban: What's in a Name?', The Atlanticist February 25 2009. http://www.atlanticcouncil.org/blogs/new-atlanticist/taliban-whats-ina-name ; Frederick W. Kagan, Finding the Target: The Transformation of American Military Policy (New York: Encounter Books 2006).

56 J.S. Coleman, Foundations of Social Theory (Cambridge, MA: Harvard UP 1990).

57 Mullah Sadiq was known to the British as Mullah Sadiquallah.

58 Carleton-Smith (note 37).

59 Samuel M. Katz, 'The Hunt for the Engineer', Connecticut: Lyons Press 2002. pp. 271-284

60 UK Ministry of Defence, Afghanistan Casualty and Fatality Tables, https://www.gov. uk/government/uploads/system/uploads/attachment_data/file/251261/20131017-Op_Herrick_casualty_upto_30September13.pdf (accessed July 30 2011); The Guardian, 'British dead and wounde $\bar{d}$ in Afghanistan, month by month', The Guardian, 'British dead and wounded in Afghanistan, month by month', The Guardian Datablog, May 2011, <www.guardian.co.uk/news/datablog/2009/sep/17/afghanistan-casualties-dead-woundedbritish-data\#data> (accessed June 17 2011); Anthony H. Cordesman and Jason Lemieux, IED Metrics for Afghanistan January 2004-May 2010, < http://images.defensetech.org/ wp-content/uploads//2010/07/JIEDDO-Report.pdf>, (Washington DC: Center for Strategic and International Studies 2011).

61 Stephen Grey,'Key Taliban Leaders in Afghanistan Eliminated'. ABC News Online, 24 July 2008, <http://abcnews.go.com/Blotter/story?id=5436787> (accessed June 16 2011).

62 Shachtman (note 4).

63 BBC News, 'Chechen rebel chief Basayev dies', BBC News Online, July 10 2006, <http://news.bbc.co.uk/1/hi/5165456.stm> (accessed June 18 2011).

64 Alex D. Barker, 'Improvised Explosive Devices In Southern Afghanistan and Western Pakistan, 2002-2009', New America Foundation, April 2010, <http://counterterrorism.newamerica.net/sites/newamerica.net/files/policydocs/barker3.pdf> (accessed June 20 2011). 
65 NATO, 092 STC 11 E - Countering The Afghan Insurgency: Low Tech Threats, HighTech Solutions. NATO Parliamentary Assembly. Spring 2011. Anthony H. Cordesman, The Afghan-Pakistan War: New ISAF Reporting on Key Trends, CSIS (February 10. 2009), 4-6; Cordesman and Lemieux (note 62).

66 Hart, Michael, Former Chief ISAF Chief J2. . Interview by Keith Dear. (March 31 2011).

67 Barker (note 64).

68 Ibid.

69 BBC 2006 (note 64); Stew Magnuson, 'Weapons of Choice: Bomb Making Skills Spread Globally: Improvised Explosive Devices', National Defense 91 (2007) pp.27-9.

70 Al Jazeera, 'Senior al Qaeda Leader Killed in Afghanistan', Al Jazeera, April 26 2011, < http://english.aljazeera.net/news/asia/2011/04/201142610015549290.html (accessed July 30 2011)>.Name withheld, Security Service Analyst, interview by Keith Dear (date undisclosed).

71 Roggio (note 5).

72 Mark Urban, Big Boy's Rules: The SAS and the Secret Struggle Against the IRA (London: Faber 1992), pp. 218-19; Peter Taylor, Brits: The War Against the IRA (London: Bloomsbury Publishing 2001),pp.256-7; Ed Moloney, A Secret History of the IRA (London: Penguin Books 2002) pp.291, 307, 313.

73 Urban (note 72) pp.227-37.

74 Moloney (note 72) pp.313-19.

75 Urban (note 72) p.243.

76 The Telegraph, 'Antrim soldiers shooting: Dead soldiers just minutes from leaving for Afghanistan', The Telegraph Online, March 9 2009, <www.telegraph.co.uk/news/uknews/ northernireland/4959722/Antrim-soldiers-shooting-Dead-soldiers-just-minutes-fromleaving-for-Afghanistan.html> (accessed June 18 2011);Moloney (note 74) pp.324-5.

77 Mannes (note 12) p.43.

78 Roggio (note 5).

79 Adam Entous,'US sees signs of disarray within Pakistani Taliban', Reuters, August 12. 2009; Nickols (note 37); Turner (note 37).

80 Petraeus (note 3 ).

81 Richard P. Mills, 'US Marine Corps History Division: Oral History Interview - Field Report: Interviewee Mills, Richard P. Maj Gen', Institute for the Study of War, May 2 2011, p.8, <www.understandingwar.org/files/MajGen_Mills_2May2011.pdf> (accessed June 2 2011).

82 Sherard Cowper-Coles, Cables from Kabul: The Inside Story of the West's Afghanistan Campaign (London: HarperPress 2011) p.278; Joshua Partlow, 'Haqqani insurgent group proves resilient foe in Afghan war', Washington Post, May 29 2011, <www.washingtonpost.com/world/asia-pacific/haqqani-insurgent-group-proves-resilient-foe-in-afghan-war/ 2011/05/27/AG0wfKEH_story.html> (accessed June 21 2011).

83 PBS Frontline (in the US) Channel 4 Dispatches (in the UK), 'Kill/Capture (US) America's Secret Killers (UK)', PBS Frontline and Channel 4 Dispatches, June 6 2011, $<$ www.pbs.org/wgbh/pages/frontline/kill-capture/etc/transcript.html> and <www.channel4.com/programmes/dispatches/episode-guide/series-92/episode-1> (accessed June 12 2011).

84 Herschel Smith, 'High Value Target Campaign is Failing in Afghanistan', The Captain's Blog, October 27. 2010, <www.captainsjournal.com/2010/10/27/high-value-target-campaign-isfailing-in-afghanistan/> (accessed 15 June 2011); Herschel Smith, 'HVTs and the Taliban Decapitation Campaign', The Captain's Blog, September 12. 2010, <www.captainsjournal.com/2010/09/12/hvts-and-the-taliban-decapitation-campaign/> (accessed June 15 2011).

85 Griffe Witte, 'Taliban establishes elaborate shadow government in Afghanistan', Washington Post, December 8. 2009; Elizabeth Lee Walker, 'Culturally-Attuned Governance and Justice in Helmand Province, Afghanistan', ISAF, April 2010; C.J. Chivers, 'In Eastern Afghanistan, at War With the Taliban's Shadowy Rule', New York Times, February 6. 2011, <www.nytimes.com/2011/02/07/world/asia/07taliban.html?_r=1>. 
86 Steven R. David, 'Fatal Choices: Israel's Policy of Targeted Killing', Mideast Security and Policy Studies No. September 51 2002; Reuters, 'Factbox: Doku Umarov and North Caucasus rebellion', Reuters, February 8. 2011, <www.reuters.com/article/2011/02/08/usrussia-umarov-factbox-idUSTRE71740820110208> (accessed June 18 2011).

87 Dorronsoro (note 7)

88 Anthony Heath, Rational Choice and Social Exchange (Cambridge: CUP 1976), p.3; Alexandre Wilner, 'Deterring Terrorism: Lessons from Afghanistan', Centre for Foreign Policy Studies, March 15 2008, 1-3 <http://centreforforeignpolicystudies.dal.ca/pdf/ gradsymp08/Wilner.pdf > (accessed July 2 2011).

89 Ariel Merari, "Deterring Fear: Government Responses to Terrorist Attacks." Harvard International Review, 2006 (Merari 2006), p.3.

90 Jeff Victoroff, 'The Mind of the Terrorist : A Review and Critique of Psychological Approaches', Journal of Conflict Resolution 49/3 (2005), pp.14-17.

91 Paul Bellaby and David Lawrenson, 'Approaches to the Risk of Riding Motorcycles: Reflections on the Problem of Reconciling Statistical Risk Assessment and Motorcyclists' Own Reasons for Riding', Sociological Review 49/3 (2001), pp.368-88.

92 ISAF, 'ISAF Issues Guidance on Night Raids in Afghanistan', ISAF News Room, 5 April 2010, <www.isaf.nato.int/article/isaf-releases/isaf-issues-guidance-on-night-raidsin-afghanistan.html> (accessed July 3 2011).

93 M. Brooke Rogers, Kate M. Loewenthal, Christopher Alan Lewis, Richard Amlot, Marco Cinnirella, and Humayan Ansari, 'The role of religious fundamentalism in terrorist violence: A social psychological analysis', International Review of Psychiatry (2007), p.255 of pp.253-62.

94 Fathali M. Moghaddam, 'The Staircase to Terrorism: A Psychological Exploration', American Psychologist, 2005, pp. 161-9.

95 Gen. Stanley McChrystal, 'Address to the International Institute for Strategic Studies', Special Address: Transcript. London: IISS, October 1. 2009.

96 Robert Gildea, Marianne in Chains: In Search of the German Occupation of France 1940-45 (London: Macmillan 2002), pp.243-84.

97 Winnifred R. Louis, and Donald M. Taylor, 'Understanding the September 11 Terrorist Attack on America: The Role of Intergroup Theories of Normative Influence', Analyses of Social Issues and Public Policy 2002, pp.87-100; Winnifred R. Louis, 'If they're not crazy, then what? The implications of social psychological approaches to terrorism for conflict management', In Stephan Lewandowsky, David Denemark, Joseph Clare, Frank Morgan and Werner G. K. Stritzke, Terrorism and Torture: An Interdisciplinary Perspective (New York: CUP 2009) pp.125-53.

98 John Horgan, Walking Away from Terrorism: Accounts of Disengagement from Radical and Extremist Movements (Abingdon: Routledge 2009) pp. 56-7, pp.60-76.

99 John Drury and Chris Cocking, The Mass Psychology of Disasters and Evacuations: A Research Report and Implications for Practice (Brighton: Univ. of Sussex 2007) p.17.

100 Louis and Taylor (note 97) p.91.

101 America's Defense Monitor, 'The Limits of Air Power - Documentary Transcript', ADM Online, 8 Aug. 1999 <www.cdi.org/adm/1248/transcript.html> (accessed June 13 2011).

102 Paul Johnson, A History of the American People (New York: Weidenfield 1997) p.25; Donald, I. \& Canter, D. (1992) "Intentionality and fatality during the King's Cross Underground fire." European Journal of Social Psychology, 22/3, pp.203-218. p.204; Anthony R. Mawson, 'Understanding Mass Panic and Other Collective Responses to Threat and Disaster', Psychiatry: Interpersonal and Biological Processes 2005 68/2, pp. 95-113.

103 Mills (note 81) p.8.

104 Elliot Aronson and Judson Mills, The Effect of Severity of Initiation on Liking for a Group (US Army Leadership Human Research Unit 1958).

105 Marc Sageman, Leaderless Jihad (Univ. of Pennsylvania Press 2008).

106 Jason Burke, Al-Qaeda (London: 2011, 2007) pp. 264-8; Andrew Hansen and Lauren Vriens. Al Qaeda in the Islamic Maghreb (New York: Council of Foreign Relations 2009); 
Alistair Harris, Yemen on the Brink: Exploiting Grievances: Al Qaeda in the Arabian Peninsula (Washington DC: Carnegie Endowment for International Peace 2011).

107 Rafaello Pantucci, 'Terror in Germany: An Interview with Guido Steinberg', International Center for the Study of Radicalisation: FREEradicals Blog, March 16 2011, <http://icsr.info/ blog/contributor/Raff-Pantucci> (accessed March 28 2011); Kim Seguputa, 'Army is Fighting British Jihadists in Afghanistan', The Independent, February 25. 2009 <www.independent.co.uk/news/world/asia/exclusive-army-is-fighting-british-jihadistsin-afghanistan-1631347.html>; EUROPOL, 'EU Terrorism Situation and Trend Report 2010', Europol. $2010<$ www.europol.europa.eu/publications/EU_Terrorism_Situation_and_Trend_Report_TE-SAT/TESAT2010.pdf (accessed February ${ }^{-}$7. 2011); Janet Napolitano, Interview by House of Representatives Committee on Homeland Security 'Understanding the Homeland Threat Landscape - Considerations for the 112th Congress'. 'Secretary of State, Department of Homeland Security', Testimony (February 9. 2011); Jonathan Bronitsky, British Foreign Policy and Bosnia: The Rise of Islamism in Britain 1992-1995 (London: International Centre for the Study of Radicalisation and Political Violence 2010).

108 John Bew, Martyn Frampton, and Inigo Gurruchaga, Talking to Terrorists: Making Peace in Northern Ireland and the Basque Country (London: C. Hurst 2009); pp.52 and 178; Moloney (note 72) p. 291, 307, 313; Taylor (note 72) pp.219-20; Mannes (note 12); Jordan (note 13) p.730.

109 Thomas Harding, 'Afghan insurgents "on brink of defeat"،, Telegraph, 1 June 2008. <www.telegraph.co.uk/news/newstopics/onthefrontline/2062440/Afghanistans-Talibaninsurgents-on-brink-of-defeat.html> (accessed June 12011 ).

110 Caroline Gammell, 'War in Afghanistan cannot be won, British commander Brigadier Mark Carleton-Smith warns', Telegraph, Oct 5 2008. ; Cowper-Coles (note 84) p.282.

111 Mills (note 81) p.36.

112 Alex Strick van Linschoten and Felix Kuehn, 'Separating the Taliban from al-Qaeda: The Core of Success in Afghanistan', New York Univ., Feb. 2011, p.6, pp.9$11<$ www.cic.nyu.edu/afghanistan/docs/gregg_sep_tal_alqaeda.pdf> (accessed June 23 2011).Sageman and Hoffman (note 46) pp.131-2; Bergen (note 37) p.317.

113 Roggio, 'Taliban Cooperation With Al Qaeda Is 'At The Highest Limits' Claims Siraj Haqqani, April 15 2010).

114 Lieven (note 24) pp.420-1.

115 Jayshree Bajoria, Pakistan's New Generation of Terrorists (Washington DC: Council on Foreign Relations 2011) p.2.

116 Pir Zubair Shah, Sabrina Tavernise and Mark Mazzetti, 'Taliban Leader in Pakistan Is Reportedly Killed', New York Times, August 7 2009.; William O“Hara, 'Drone Attacks and Just War Theory', Small Wars Journal (2010). p.11; http://smallwarsjournal.com/jrnl/ art/drone-attacks-and-just-war-theory

117 Peter Bergen and Katherine Tiedemann, 'Revenge of the Drones', New America Foundation, October 19 2009. http://peterbergen.com/revenge-of-the-drones/

118 Entous (note 79); Stewart (note 25) p.7; Ismail Khan and Lydia Polgreen, 'New Leader of Pakistan's Taliban Is Named, Though Officials Believe He Is Dead', New York Times, August 22 2009.; Alamgir Bitani, 'US says evidence Taliban chief dead "pretty conclusive", Reuters August 9 2009. http://www.reuters.com/article/2009/08/09/idUSISL181950._CH_.2400; Kamila Hyat, 'The Future after Baitullah', The News International (Pakistan), August 13 2009. http://thebeautifulpakistan.blogspot.co.uk/2009/ 08/future-after-baitullah.html; Ron Moreau and Sami Yousafzai, 'The End of Al Qaeda?', Newsweek, August 72009.

119 Bajoria (note 115) p.3; Mahmood, Javed. 'TTP, Other Militant Outfits Merge'. Central Asia Online. Jan 1 2011. http://centralasiaonline.com/cocoon/caii/xhtml/en_GB/features/ pakistan/main/2011/01/11/feature-01 (accessed June 24 2011).

120 Jason Burke, 'Pakistan Taliban vow to attack US targets overseas', Guardian Online, 7 June 2011, <www.guardian.co.uk/world/2011/jun/07/pakistan-taliban-attack-us-targets>. (accessed June 24 2011). 
121 Louis (note 97).

122 Robert Baron, 'So right it's wrong: Groupthink and the ubiquitous nature of polarized group decision-making', Advances in Experimental Social Psychology 37/212 (2002), 219-53.

123 Louis and Taylor (note 98); Clark McCauley and Sophia Moskalenko, 'Mechanisms of Political Radicalization: Pathways Toward Terrorism', Terrorism and Political Violence 20/3 (2008) pp.421-2 of pp.415-33; Philip Zimbardo, The Lucifer Effect: How Good People Turn Evil (London: Ebury Publishing 2009) pp.267-78; Moghaddam (note 96); Marc Sageman, Understanding Terror Networks (Univ. of Pennsylvania Press 2004); Sageman (note 106) pp.84-8.

124 Katherine Collins, 'Clan, Pacts and Politics in Central Asia', Journal of Democracy 13/3 (July 2002); William A. Haviland, Harald E. L. Prins, Bunny McBride and Dana Walrath, Cultural Anthropology: The Human Challenge (London: Wadsworth Publishing 2007) p.249.

125 McChrystal (note 95).

126 M. Ibrahim Atayee, A Dictionary of the Terminology of Pashtun's Tribal Customary Law and Usages, International Centre for Pashto Studies, trans. A. Mohammed Shinwary (Academy of Sciences Afghanistan 1979) p.11; TRADOC G2 Human Terrain System, My Cousin's Enemy is My Friend: A Study of Pashtun 'Tribes' in Afghanistan. Afghan Research Reachback Center White Paper (Fort Leavenworth, Kansas: United States Army 2009).

127 Alison Cathcart, 'Kinship and Clientage: Highland Clanship 1451-1609, Northern World, 20. (Leiden, Netherlands: Brill). Abduba Mollu Ido, 'Somalia: Who is Next? The Cycle of Revenge Killings', Helo Magazine, March 4 2010, <http://helomagazine.org/journeys/ 2010/3/4/somalia-who-is-next-the-cycle-of-revenge-killings.html> (accessed 30 July 2011); pp. 55-57; Sarah Phillips, 'Yemen and the Politics of Permanent Crisis: Yemen and the 2011 Arab Uprisings', IISS Adelphi Series Vol. 51 Issue 420, Chapter 7, (London: IISS, 2011), p.128. Lieven (note 24) p.218, pp.353-6, pp.385-7.

128 Lieven (note 24) pp.218-19.

129 Ibid.

130 Rodric Braithwaite, Afgantsy: The Russians in Afghanistan 1979-89 (London: Profile Books 2011) pp.183-4.

131 David B. Edwards, Before Taliban: Genealogies of the Afghan Jihad (Berkeley: Univ. of California Press 2002), 140.

132 TRADOC (note 126); Atayee (note 127).

133 Haviland et al. 2007 (note 124) p. 249.

134 Bergen (note 117) p.3.

135 Jean MacKenzie, The Battle for Afghanistan: Militancy and Conflict in Helmand, Counterterrorism strategy initiative policy paper (New America Foundation 2010) p.11.

136 Mannes (note 12); Jordan (note 13).

137 Mannes (note 12).

138 Antonio Giustozzi and Christopher Reuter, The Insurgents of the Afghan North (Kabul/ Online: Afghan Analysts Network 2011) p.3, pp.28-32; Antonio Giustozzi, Academic and Afghan Analyst, interview by Keith Dear, March 72011.

139 Mills (note 81) p.36.

140 Stephen Masty, 'How to turn Taliban warlords into allies', The Telegraph Online, 10 Nov. 2001, <www.telegraph.co.uk/news/worldnews/1362072/How-to-turn-Taliban-warlordsinto-allies.html> (accessed June 23 2011).

141 Wood (note 7).

142 Linschoten and Kuehn (note 112) p.6, pp. 9-11; Sageman (note 106) pp.131-2; Bergen (note 36) p. 317.

143 Hart (note 51); Giustozzi (note 138).

144 Stephen Grey, 'Cracking on in Helmand', Prospect Magazine Online, August 27. 2009, p.311, <www.prospectmagazine.co.uk/2009/09/cracking-on-in-helmand/> (accessed 9 August 2009).

145 Ben Farmer, 'Afghanistan sees new breed of dangerous young Taliban leader', The Telegraph Online, December 2. 2010, <www.telegraph.co.uk/news/worldnews/asia/ 
afghanistan/8176768/Afghanistan-sees-new-breed-of-dangerous-young-Taliban-leader.html > (accessed June 22 2011).

146 Alistair Horne, A Savage War of Peace: Algeria 1954-1962 (New York: NYRB 2006)p. 230.

147 Ibid. p.161.

148 Brian Glynn Williams, 'Mullah Omar's Missiles: A Field Report on Suicide Bombers in Afghanistan', Middle East Policy Council, May 2007, <www.mepc.org/journal/middleeast-policy-archives/mullah-omars-missiles-field-report-suicide-bombers-afghanistan? print> (accessed June 23 2011).

149 Ibid. The Washington Times, 'Taliban field manual: A kinder, gentler militant?' The Washington Times Online, July 30 2009, <www.washingtontimes.com/news/2009/jul/30/akinder-gentler-taliban/?page =all\# pagebreak $>$ (accessed June 23 2011); Kate Clark, 'The Layha: Calling the Taliban to Account', Afghan Analysts Network, July 42011. http://www.afghanistan-analysts.org/publication/the-layha-calling-the-taleban-to-account

150 Riedel (note 45) p.100.

151 Channel 4, 'Taliban Anger over Death of Ilyas Kashmiri', Channel 4 News, June 52011. http://www.channel4.com/news/taliban-anger-over-death-of-ilyas-kashmiri (accessed July 4 2011).

152 Bew, Frampton and Gurruchaga (note 108) p.109.

153 Liz Fuller, Radio Free Europe/Radio Liberty, February 14 2011, <www.rferl.org/content/ chechnya_youngest_insurgents/2308952.html> (accessed June 22 2011); Stanislav Lunev, 'The Specter Of Terror Begins To Haunt Russia', The Jamestown Foundation: Eurasia Monitor, January 26 1996. http://www.jamestown.org/single/?no_cache=1\&tx_ttnews\% 5Bswords\%5D=8fd5893941d69d0be3f378576261ae3e; Andrei Smirnov, 'Who Attacked Beslan? Profiling The Terrorist Group', The Jamestown Foundation: Eurasia Daily Monitor, October 6 2004, <www.jamestown.org/single/?no_cache=1\&tx_ttnews\%5Bswords\% $5 \mathrm{D}=8 \mathrm{fd} 5893941 \mathrm{~d} 69 \mathrm{~d} 0 \mathrm{be} 3 \mathrm{f378576261ae3e \& tx+ttnews} \% 5 \mathrm{Bany}$ of the - words $\% 5 \mathrm{D}=\mathrm{Ba}-$ sayev\&tx_ttnews\%5Bpointer\%5D $=2 \& t x$ ttnews $\% 5 B t t$ news $\% 5 \bar{D}=26954 \&$ tx_ttnews $\%$ $5 \mathrm{BbackPid} \% 5 \mathrm{D}=78 \mathrm{cHash}=30 \mathrm{~b} 8 \mathrm{f} 7318 \mathrm{fe} 4 \mathrm{a} 60 \mathrm{~b} 4 \mathrm{c} 81 \mathrm{f02541} \mathrm{ccec} 1>$ (accessed June 18 2011); Andrew McGregor, 'Islam, Jamaats and Implications for the North Caucasus', The Jamestown Foundation: Eurasia Monitor, June 15 2006, <www.jamestown.org/single/?no_cache $=1 \&$ tx_ttnews $\% 5$ Bswords $\% 5 \mathrm{D}=8 \mathrm{fd} 5893941 \mathrm{~d} 69 \mathrm{~d} 0 \mathrm{be} 3 \mathrm{f} 378576261 \mathrm{ae} 3 \mathrm{e} \& \mathrm{tx}$ _ttnews $\%$ 5Bany_of_the_words $\% 5 \mathrm{D}=$ Basayev\&tx_ttnews $\% 5 \mathrm{Bpointer} \% 5 \mathrm{D}=1 \& \mathrm{tx}$ ttnews $\% 5 \mathrm{Btt}$ news $\% 5 \mathrm{D}=808 \& \mathrm{tx}$ tttnews $\% 5 \mathrm{BbackPid} \% 5 \mathrm{D}=7 \& \mathrm{cHash}=\mathrm{b} 4 \mathrm{e} 06 \mathrm{ec} 71 \mathrm{ab} 83 \mathrm{~d} 5 \mathrm{aea} 0945 \mathrm{fc} 1 \mathrm{e} \overline{2}$ 53369> (accessed June 18 2011); Cerwyn Moore, 'The Roots and Transformation of the Dagestan Insurgency', The Jamestown Foundation: Eurasia Monitor, September 30 2010, <www.jamestown.org/single/?no_cache $=1 \&$ tx_ttnews $\% 5 B$ swords $\% 5 \mathrm{D}=8 \mathrm{fd} 5893941 \mathrm{~d} 69$ d0be3f378576261ae3e\&tx_ttnews\%5Bany_of_the_words\%5D=Basayev\&tx_ttnews\%5Btt_ news $\% 5 \mathrm{D}=36972 \&$ tx_ttnews $\% 5$ BbackPid $\% 5 \bar{D}=\overline{7} \& \mathrm{cHash}=77 \mathrm{a} 27 \mathrm{~b} 135 \mathrm{de} 4 \mathrm{a}-$

c32a081a9198ecc4329> (accessed June 18 2011); BBC News, 'Chechen rebel chief Basayev dies', BBC News Online, July 10 2006, http://news.bbc.co.uk/1/hi/5165456.stm (accessed June 18 2011); RFE/RL, 'As Hit Men Strike, Concern Grows Among Chechen Exiles', Radio Free Europe/Radio Liberty, March 12 2009, <www.rferl.org/content/ As_Hit_Men_Strike_Concern_Grows_Among_Chechen_Exiles/1508931.html> (accessed Juñe 20 2011).

154 Mordechai Kedar, 'Hamas and Fatah: A Temporary Marriage of Convenience', The Begin-Sadat Center for Strategic Studies, May 12 2011, <www.biu.ac.il/Besa/perspectives138.html> (accessed June 22 2011).

155 Bew, Frampton and Gurruchaga (note 108) p.176.

156 Ibid. p.178.

157 Mills (note 81); Amir (note 37); Nickols (note 37); Ashraf (note 38).

158 Urban (note 72) pp.218-19; Taylor (note 72) pp.256-57.

159 Daniel Byman, 'Taliban vs. Predator: Are Targeted Killings Inside Pakistan a Good Idea?' Foreign Affairs, Aug. 2009.

160 Zahid Hussain and Michael Evans, 'Drone attacks in tribal Pakistan force al-Qaeda into urban areas', The Times, London, August 82009. 
161 Lieven (note 24); Selig S. Harrison, 'America Builds Pashtunistan', The National Interest, February 28 2011: http://nationalinterest.org/commentary/america-builds-pashtunistan4928; AFP, 'CIA Won't Halt Operations in Pakistan: Official', Pakistani Daily Times, April 16 2011, <www.dailytimes.com.pk/default.asp?page $=2011 \% 5$ C04\%5C16\%5Cstory_164-2011_pg1_3> (accessed June 4 2011); Christina Lamb, 'Stop bombing us: Osama isn't here, says Pakistan', The Times, London July 12 2009. p.2.

162 Jamestown Foundation, 'North Caucasus Low-Grade Insurgency Continues to Simmer', Eurasia Daily Monitor 8/131, July 82011.

163 PBS/Channel 4 (note 83).

164 Anne W. Patterson, 'Reviewing our Afghanistan-Pakistan Strategy', U.S. Embassy Cables, September 23 2009. http://www.theguardian.com/world/us-embassy-cables-documents/ 226531

165 Jason Burke, 'Pakistan Taliban vow to attack US targets overseas', Guardian Online, June 7 2011, <www.guardian.co.uk/world/2011/jun/07/pakistan-taliban-attack-us-targets > (accessed June 24 2011).

166 Ibid.

167 Taylor (note 72) p.153.

168 Ibid. pp.278-81; Urban(note 72) p.243.

169 Fuller (note 153); Lunev (note 153); Smirnov (note 153); McGregor (note 153); Moore (note 153); BBC News (note 153); RFE/RL (note 153).

170 Michael Burleigh, Blood and Rage: A Cultural History of Terrorism (Harper Press 2008) pp.6-7; Friedrich Engels, 'Letters to Marx', <www.marxists.org/archive/marx/works/ 1867/letters/67_11_24.htm> (accessed August 18 2011).

171 Burleigh (note 170) p.225; Richard Huffman, 'Baader-Meinhoff.com', <www.baadermeinhof.com/timeline/1967.html> (accessed August 18 2011).

172 Urban (note 72) pp.82-3.

173 Urban (note 72) p.243.

174 Dorronsoro (note 7) p.15.

175 L. Carl. Brown, Religion and State: The Muslim Approach to Politics (Chichester, UK: Columbia UP 2000) pp.141-60; Burke (note 106) pp.47-55.

176 Burke (note 106) pp.73-5.

177 Ed Husain, The Islamist: Why I joined Radical Islam in Britain, What I Saw Inside and Why I Left (London: Penguin 2007) pp. 36-38 and 47-52.

178 Bergen (note 36) p.33.

179 Bruce Hoffman, Trends in Terrorism and Future Potentialities: An Assessment (Santa Monica, CA: RAND 2003) p.13.

180 Owen (note 12).

181 E.g. Yakov Katz, 'So Targeted Killings Do Work, After All', Jerusalem Post, 6 May 2011, <www.jpost.com/Features/FrontLines/Article.aspx?id=219439> (accessed 30 July 2011).

182 Keppel, G. and Milleli, eds., Al Qaeda in its own words. (Cambridge, Mass and London: Harvard, 2008).

183 Zimbardo (note 123) pp.227-8, 266-76, 454-5.

184 Ibid. pp.454-5.

185 Edward Skidelsky, 'Words that Think For Us', Prospect Magazine, Regular column, April 2010, p.82.

186 Timothy McHale, 'Memorandum for Commander United States Forces Afghanistan/ International Security Assistance Force Afghanistan: Executive Summary for AR 15-6 Investigation 21 Feb 2010 CIVCAS Incident in Uruzgan Province', May 282010. http://www.isaf.nato.int/images/stories/File/April2010-Dari/May2010Revised/Uruzgan\% 20investigation\%20findings.pdf

187 Zimbardo (note 123) p.441.

188 Robert K. Ackerman, 'Neutralizing the Network to Defeat IEDs', AFCEA, April 2011, $<$ www.afcea.org/signal/articles/templates/Signal_Article_Template.asp?articleid $=2575 \&$ zoneid $=313>$ (accessed June 29 2011) . 
189 Stanley Wasserman and Katherine Faust, Social Network Analysis: Methods and Applications (Structural Analysis in the Social Sciences) (Cambridge: CUP 1994) p.18; John Scott, Social Network Analysis (Sage Publications 2000) p.5.

190 Nancy Howell Lee, The Search for an Abortionist (Univ. of Chicago Press 1969) cited in Scott (note 189).

191 J. Jonas and J. Harper, Effective Counterterrorism and the Limited Role of Predictive Data Mining (Washington DC: Cato Institute) p.7.

192 Hafez and Hatfield (note 13); James Dao and Dalia Sussman, 'For Obama, Big Rise in Poll Numbers After Bin Laden Raid', New York Times Online, May 42011.

193 Mina Habib and Shahpoor Saber, 'Taleban Bruised by Bin Laden Killing', Institute for War and Peace Reporting, May 13 2011, < http://iwpr.net/report-news/taleban-bruisedbin-laden-killing > (accessed June 3 2011); Alia Brahimi, 'The 'changing' face of al-Qaeda', Al Jazeera, July 5 2011. http://www.aljazeera.com/indepth/opinion/2011/07/ 20117316726986909.html

194 Grey (note 144); David Betz and Anthony Cormack, Iraq, Afghanistan and British Strategy (Washington DC: Foreign Policy Research Institute Spring 2009).

195 Stewart (note 25) p.9.

196 Bew, Frampton and Gurruchaga (note 108) p.64.

197 Robin Moore, Hunting Down Saddam: The Inside Story of the Search and Capture (New York: St Martin's Press 2004).

198 Al-Jazeera, (note 70).

199 Richard Szafranski, 'Neocortical Warfare: the ACME of Skill', in John Arquilla and David Ronfeldt (eds.), In Athena's Camp: Preparing for Conflict in the Information Age (Santa Monica, CA: RAND 1997) pp.404 and 408 of pp.395-416.

200 Gen. James N. Mattis, USJFCOM Commander's Guidance for Effects-based Operations (Carlisle, PA: US Army War College 2008).

201 Audrey Curth Cronin, How Terrorism Ends (Woodstock, UK: Princeton UP 2009) pp.27-38; Patrick B Johnstone, 'Does Decapitation Work? Assessing the Effectiveness of Leadership Targeting in Counterinsurgency Campaigns', International Security, 47-79/36 (Spring 2012) p.3; Paul W. Staeheli, Collapsing Insurgent Organizations Through Leadership Decapitation: A Comparison Of Targeted Killing And Targeted Incarceration In Insurgent Organizations, (Monterey, CA: Naval Postgraduate School), pp.54-61.

202 Ben Connable and Martin Libicki, How Insurgencies End, (Online: RAND 2010) p.82. http://www.rand.org/content/dam/rand/pubs/monographs/2010/RAND_MG965.pdf

203 Cronin (note 201) pp.27-8.

204 Paikiasothy Saravanamuttu, 'A year after the defeat of the LTTE, human rights are still pivotal in Sri Lanka', The Telegraph Online, May 9 2010, www.telegraph.co.uk/news/ worldnews/asia/srilanka/7739727/A-year-after-the-defeat-of-the-LTTE-human-rightsare-still-pivotal-in-Sri-Lanka.html (accessed June 21 2011).

205 Vines A. and Oruitemeka B., 2008, 'Bullets to ballots: The reintegration of UNITA in Angola', Conflict, Security and Development, 8/2 (2008), pp.241-63.

206 Staeheli (note 201) p.23, pp.46-53; Johnstone (note 201) p.7; Paul Wilkinson, Email to Sqn Ldr Dear, July 21 and 222011.

207 Burleigh (note 170) pp.256 and 266.

208 Rajesh Venugopal, 'Sectarian Socialism: The Politics of Sri Lanka's Janatha Vimukthi Peramuna (JVP)', Modern Asian Studies 44/3 (2010), pp.567-8 and 570-1 of pp.567-602.

209 Bassam Yousef Ibrahim Banat, 'Palestinian Youth and the Rush Towards Martyrdom', Journal of Society and Heritage No. 51 (2010), Social Science Research Network, pp.5-6, $<$ http://papers.ssrn.com/sol3/papers.cfm?abstract_id=1549527>; Staeheli (note 201) pp.48, 51.

210 Connable and Libicki (note 202) p.iii; Seth G. Jones and Martin C. Libicki, How Terrorist Groups End: Implications for Countering al Qaeda (Online: RAND 2008) p.v.

211 Cronin (note 201); Martha Crenshaw (ed.), The Consequences of Counterterrorism (New York: Russell Sage Foundation 2010).

212 Wilkinson (note 206). 
213 Philip Alston, UN Special Rapporteur on Extrajudicial, Summary or Arbitrary Executions: Study on Targeted Killings, Human Rights Council Report (New York: United Nations General Assembly 2010) p.21.

214 The Supreme Court of the State of Israel, The Supreme Court Sitting as the High Court of Justice Decision on Targeted Killing, HCJ 769/02, Tel Aviv: The State of Israel 2005.

215 Ibid.

216 Thomas H. Henricksen, The Israeli Approach to Irregular Warfare and Implications for the United States, JSOU Report 07-03 (Hurlburt Field, FL: Joint Special Operations Univ. 2007) p.18.

217 David (note 86) p.7.

218 Urban (note 72) pp.8, 163-5, 170, 247.

219 Ibid. pp.227-37.

220 C.F.A. Portal, 'Air Force Co-operation in Policing the Empire', RUSI Journal, 82/526 (1937), pp. 343-358.

221 Ibid. p.354. 